\title{
Konstytucje ,egzorbitancyjne” w Rzeczypospolitej w latach 1607-1648. Zarys problematyki
}

\section{Problem klasyfikacji efektów działalności legislacyjnej sejmów} walnych. Dla każdego badacza przedrozbiorowego sejmu walnego okres, którego początek wyznacza rokosz Zebrzydowskiego, a koniec śmierć króla Władysława IV i nakładający się na nią początek katastrofalnych i wyniszczających wojen, ma znaczenie szczególne. Nie bez powodu właśnie ten etap w dziejach staropolskiego parlamentaryzmu doczekał się zdecydowanie największej liczby opracowań monograficznych, zogniskowanych na znaczeniu politycznym, pozycji ustrojowej i funkcjonowaniu proceduralnym sejmu walnego ${ }^{1}$. Doświadczenia końcowych lat panowania króla Stefana Batorego oraz początkowego okresu rządów Zygmunta III, naznaczonych destrukcyjnymi konfliktami i kryzysami, zwieńczonymi wojną domową, stanowiły dla dworu monarszego, senackiej elity i szlacheckiego narodu

${ }^{1}$ Należy tu wskazać liczne monografie określonych sejmów za panowania Zygmunta III w okresie porokoszowym, przede wszystkim: J. Byliński, Sejm z roku 1611, Wrocław 1970; idem, Dwa sejmy z roku 1613, Wrocław 1684; S. Ochmann-Staniszewska, Sejmy z lat 1615-1616, Wrocław 1970; J. Seredyka, Sejm 1618 roku, Opole 1988; idem, Sejm w Toruniu z 1926 roku, Wrocław 1966; idem, Sejm zawiedzionych nadziei, Opole 1981; idem, Rzeczpospolita w ostatnich latach panowania Zygmunta III (1629-1632). Zarys wewnętrznych dziejów politycznych, Opole 1978; J. Pietrzak, Po Cecorze i podczas wojny chocimskiej: sejmy z lat 1620 i 1621, Wrocław 1983; J. Kwak, Sejm warszawski 1626 roku, Opole 1985; A. Filipczak-Kocur, Sejm zwyczajny z roku 1629, Warszawa/Wrocław 1979. Ważną pracę dotyczącą ustawodawczej działalności wszystkich sejmów odbywanych za panowania Zygmunta III napisała I. Lewandowska-Malec, Sejm walny koronny Rzeczypospolitej Obojga Narodów i jego dorobek ustawodawczy, Kraków 2009. Sejmy z czasów Władysława IV cieszą się mniejszą popularnością, jedyna monografia poświęcona została sejmowi z 1637 r., który rozszedł się bez powzięcia uchwał, por. R. Kołodziej, Pierwszy sejm z 1637 roku, Toruń 2003. Sejmom nadzwyczajnym w okresie panowania drugiego Wazy na polskim tronie odrębne studium poświęcił P. Paradowski, W obliczu ,naglych potrzeb” Rzeczypospolitej. Sejmy ekstraordynaryjne za panowania Władysława IV Wazy, Toruń 2005 r. Wszystkim sejmom panowania Władysława IV poświęcono dwie pozycje ogólniejsze, choć raczej o zabarwieniu politycznym niż prawniczym, por. J. Dzięgielewski, Izba poselska w systemie władzy Rzeczypospolitej czasów Władysława IV, Warszawa 1990 oraz S. Hołdys, Praktyka parlamentarna za panowania Władysława IV Wazy, Wrocław 1991. 
dostateczną przestrogę przed lekceważeniem legalnych procedur ustrojowych $^{2}$. Szczególnie, że to właśnie sesje sejmowe z roku 1607, a zwłaszcza z 1609, pozwoliły na „pacyfikacje”” sytuacji w kraju i ustabilizowanie relacji między władcą a obywatelami. Od tego momentu, przez kilkadziesiąt lat obrady zdecydowanej większości sesji sejmowych miały charakter merytoryczny, natężenie sporów politycznych, choć spore, pozwalało na osiagnięcie wymaganego prawem konsensusu, a efektem prac trzech sejmujących stanów były uchwalane normy prawne, stanowiące odpowiedź (czasem bardziej, czasem mniej adekwatną) na problemy polityki wewnętrznej i zewnętrznej Rzeczypospolitej.

Sejm walny przez całą historię istnienia Polski szlacheckiej odgrywał w niej gigantyczną rolę w licznych sferach: społecznej, politycznej, czy nawet kulturowej, pełnił przy tym, w olbrzymim i zróżnicowanym państwie, ważną funkcję integracyjną. Nie wolno jednak zapominać, iż był to przede wszystkim organ prawodawczy (mimo że w miarę pogłębiającego się kryzysu politycznego i ustrojowo-prawnego stracił zdolność do efektywnego wypełniania swojej właściwej roli), a skomplikowany tryb obrad sejmowych oparty na fundamentalnych zasadach: zgody trzech stanów sejmujących, absolutnej nieomal swobody wypowiedzi oraz jednomyślności (braku sprzeciwu) przy podejmowaniu decyzji na forum izby poselskiej, miał doprowadzić do uchwalenia specyficznego aktu prawnego: konstytucji sejmowej ${ }^{3}$.

${ }^{2}$ Nazbyt jednowymiarowo ujmuje ten problem J. Byliński, twierdzący, iż rokosz był i być powinien przestrogą jedynie dla szlacheckich buntowników ,przed ryzykiem podejmowania tak brzemiennych w skutki działań wymierzonych przeciw panującemu władcy"; J. Byliński, Rokoszowe koncepcje reformy państwa (1606-1608), [w:] Studia historyczno-prawne. Księga poświęcona pamięci Profesora Jana Seredyki, red. W. Kaczorowski, Opole 2008, s. 62. Oceny obecne w historiografii dotyczące zasadności, bądź nie, antymonarszego wystapienia rokoszowego albo motywacji poszczególnych aktorów owego przedstawienia, nie mają większej wartości dla nauki historii prawa. $\mathrm{Z}$ perspektywy historyka ustroju bowiem istotą rokoszu było wymknięcie się konfliktu stronnictw politycznych poza ordynaryjną procedurę sejmową, co nie tylko uaktualniło próbę podjęcia egzekucji artykułu o wypowiedzeniu posłuszeństwa, ale przede wszystkim doprowadziło na kilka lat (ważnych, pełnych politycznych wyzwań), do całkowitego paraliżu sejmu, jako głównego i nieodzownego elementu konstelacji instytucjonalno-ustrojowej szlacheckiej Rzeczypospolitej.

${ }^{3}$ Trudno byłoby wskazać wszystkie prace odnoszące się do problematyki konstytucji sejmowych, najważniejsze spośród nich to: S. Grodziski, Sejm dawnej Rzeczypospolitej jako najwyższy organ ustawodawczy. Konstytucje sejmowe - pojęcie i próba systematyki, CPH, 1983, z. 1; K. Grzybowski, Systematyka prawa w Polsce Odrodzenia, jej rola i podtoże klasowe, [w:] Odrodzenie $w$ Polsce, Warszawa 1956, t. II, cz. 2, s. 1-47; idem, Teoria reprezentacji w Polsce epoki Odrodzenia, Warszawa 1959. Ciekawą próbą, bardziej przedstawienia stanu wiedzy i zaprezentowania postulatów badawczych na przyszłość niż zbiorem prac odkrywczych, jest zbiorowe opracowanie Uchwalanie konstytucji na sejmach w XVI-XVIII wieku, red. Stefania Ochmann, Wrocław 1979, które niestety nie doczekało się kontynuacji. Szereg istotnych i poprawnych prawniczo rozważań, głównie odnośnie do nieretroaktywności konstytucji, w kontekście indywidualnych przywilejów i zasady ochrony praw nabytych zawiera studium H. Grajewskiego, Granice czasowe mocy obowiqzującej norm dawnego prawa polskiego, Łódź 1970. Przede wszystkim należy wyróżnić świeżą rozprawę autorstwa I. Lewandowskiej-Malec, op. cit., patrz zwłaszcza s. 239-256; 539-586. 
Pytanie, czy konstytucje były jedynymi możliwymi rezultatami normatywnymi obrad sejmowych, budzi w nauce liczne kontrowersje. Przytoczenie wszystkich opinii na ten temat byłoby trudne technicznie i raczej niecelowe, nie stanowi bowiem właściwego przedmiotu niniejszych rozważań. Poprzestaniemy więc na wskazaniu najistotniejszych teorii w tym zakresie. W ujęciu wybitnego przedstawiciela tradycyjnej historiografii, J. Seredyki, efekty prac sejmu należy podzielić na: 1) konstytucje; 2) skrypty ad archivum; 3) dyplomy; 4) asekuracje; 5) informacje; a także 6) intencje (uchwały niespisane, stanowiące ustne, wiążące wskazania dla mianowanych przez sejm komisarzy) ${ }^{4}$. S. Grodziski stwierdził, iż ustawodawcza działalność sejmu obejmowała trzy zasadnicze kategorie aktów: 1) akty prawne „normalnego zarządu państwem”; 2) traktaty międzynarodowe oraz 3) uchwały sejmowe (które z kolei miały się dzielić na konstytucje i uniwersały poborowe) $)^{5}$. Według poglądu S. Ochmann-Staniszewskiej i Z. Staniszewskiego, wyrażonego na kartach obszernej monografii dotyczącej sejmu w czasach Jana Kazimierza, efektami działalności legislacyjnej sejmu walnego były „uchwały sejmowe”, które należy podzielić na trzy kategorie: 1) konstytucje sejmowe; 2) „deklaracje” podatkowe; 3) uchwały o charakterze organizacyjno-porządkowym (autorzy zaliczają do tej kategorii wybór senatorów rezydentów oraz członków komisji sejmowych $)^{6}$. I. Lewandowska-Malec podzieliła rezultaty normatywne prac sejmowych na: 1) uchwały sejmowe (które z kolei rozbija na trzy podgrupy: konstytucje sejmowe, uchwały podatkowe i uchwały proceduralne, tzn. recesy); 2) inne akty?

Nie ulega wątpliwości, że w Polsce przedrozbiorowej nie istniał zupełny i zamknięty katalog źródeł prawa, o określonych cechach, funkcjach, mocy prawnej itp. na wzór obecnie obowiązującego art. 87 konstytucji RP. Dlatego nazwę „konstytucje sejmowe” (podobnie jak nazwy innych ówczesnych aktów prawnych) należy traktować jako pojęcie potoczne, powstałe w wyniku zaistnienia swoistego skrótu myślowego, który wszedł do języka prawnego poprzez długotrwałe używanie w określonym kontekście ${ }^{8}$. Rozróżnienie aktów praw-

${ }^{4}$ Por. J. Seredyka, Sposoby uchwalania konstytucji na sejmach w ostatnich latach panowania Zygmunta III (1626-1632), [w:] Sposoby uchwalania konstytucji, red. S. Ochmann, s. 35.

${ }^{5}$ S. Grodziski, op. cit., s. 173.

${ }^{6}$ Por. S. Ochmann-Staniszewska, Z. Staniszewski, Sejm Rzeczypospolitej za panowania Jana Kazimierza Wazy. Prawo-doktryna-praktyka, Wrocław 2000, t. II, s. 248.

${ }^{7}$ Niestety autorka, po szerokim przedstawieniu poglądów dotychczasowych, przedstawiła swój punkt widzenia za pomocą diagramu i krótkiej wzmianki, bez bliższego uzasadnienia i sprecyzowania katalogu owych ,innych aktów”, por. I. Lewandowska-Malec, op. cit., s. 239-242.

${ }^{8}$ Odnośnie do omawianej przez nas materii, możemy stwierdzić, iż etymologicznie słowo „konstytucja” wywodzi się prawdopodobnie od łacińskiego czasownika „constituere”, używanego w specyficznych „formułach promulgacyjnych” (jak nazywa je Konstanty Grzybowski), aktów sejmowych, które nadawały moc prawną określonym rozwiązaniom przyjętym na sejmie. Podobnie słowo statut, wywodzące się zapewne od czasownika „statuere”. Opisowi owych „formuł promulgacyjnych" w zakresie ich kształtowania i stosowania, jak również przydawanego im znaczenia w prakty- 
nych następowało głównie ze względu na oczywistą kwestię kompetentnego do ich wydania podmiotu, a także legalności procedury, inne kryteria raczej lekceważono9.

Z tego względu uważamy, iż próby „rozbijania” efektów normatywnych pracy sejmu walnego na konstytucje i jakieś inne, odrębne akty są raczej nieuzasadnione. Można się tu z powodzeniem odwołać do znanej już prawu rzymskiemu paremii lege non distinguente, nec nostrum est distinguere, która zakazuje czynienia rozróżnień niemających umocowania w woli ustawodawcy, uwidocznionej w tekście aktu prawnego. Trudno się zatem nie zgodzić z W. Uruszczakiem, który skonstatował (co prawda dla realiów funkcjonowania sejmu walnego sprzed unii realnej z Litwą i pierwszej wolnej elekcji, a nawet sprzed działalności ruchu egzekucyjnego, ale to w tym przypadku bez znaczenia), iż: „termin «konstytucja» oznaczał każdą uchwałę podjętą na sejmie wspólną zgodą trzech stanów sejmujących, bez względu na jej treść, formę i range $(\ldots) " 10$.

Zgodnie z powyższym nie ma podstaw, by ,akty normalnego zarządu państwem", czyli uchwały sejmu z zakresu administracji publicznej, zakwalifikować jako uchwały sejmowe innego typu niż konstytucje, jak proponuje S. Grodziski. Trudno zgodzić się $\mathrm{z}$ tym autorem także w zakresie traktatów międzynarodowych, wstępnego parafowania umów prawa międzynarodowe-

ce legislacyjnej sejmu polskiego na przestrzeni XVI w. sporo miejsca i uwagi poświęcił we wspaniałych prawniczo rozważaniach wspomniany prof. K. Grzybowski, Teoria reprezentacji w Polsce epoki odrodzenia, Warszawa 1959, s. 191-201, a poniekąd także s. 281-293.

${ }^{9}$ Regulacja prawna uchwał sejmowych dotyczyła tylko konstytucji i jest nad wyraz lapidarna. Norma uchwalona na sejmie 1588 r. stwierdza jedynie, iż uchwały ws. konstytucji mają zapadać „na Seymie”, a ponadto, mają być ,zgodnie napisane”. Przepis wskazuje ponadto, iż gotowy akt powinni podpisać - „Pany Senatory na to deputowane” oraz „osoby (...) z Koła Poselskiego na to naznaczone”. Tekst konstytucji należało ,podać do Kancellaryej”, po czym miały być one przeczytanie w obecności króla. Ostatnim warunkiem legalności było przybicie pieczęci przez „Pany Pieczętarze” i to z dodatkowym zastrzeżeniem, ,jeśli że je My [tzn. król - T. K.] i Panowie Rady i Posłowie pieczętować każemy", por. Volumina Legum, wyd. J. Ohryzko, Petersburg 1859-1860 [dalej: VL], t. II, s. 252, fol. 1208-1209. Dodatkowym wymogiem proceduralnym było dookreślenie użytego pojęcia zgoda, za pomocą ujęcia w ścisłe ramy prawne końcowego etapu sejmowania - tzw. konkluzji, por. VL, t. III, s. 373, fol. 786 (regulacje te prezentuje bliżej H. Olszewski, Sejm..., s. 361-362). Widać wyraźnie, iż jedynymi wyznacznikami konstytucji jako źródła prawa Polski przedrozbiorowej były: 1) organ kompetentny - tzn. sejm; 2) legalna procedura uchwalenia - zgoda stanów na konkluzji obrad; 3) legalna procedura promulgacji - zwieńczona przybiciem pieczęci, w obecności pierwszego stanu sejmującego i przedstawicieli dwu pozostałych. Brak szczegółowych norm odnoszących się do zakresu przedmiotowego czy podmiotowego konstytucji albo specyfiki ich formy. Można zatem zaryzykować stwierdzenie, iż ówczesna kultura prawna pozwalała na odróżnienie normatywne aktów wydawanych przez króla (rozumianego tu, jako monokratyczny organ administracji publicznej, działający z zasady w porozumieniu z rezydentami), czy urzędników, w zakresie swych kompetencji, od tych uchwalonych zgodnie przez trzy sejmujące stany. Stąd konstytucje zakazujące ingerować królowi w materię spraw zastrzeżonych dla sejmu (nigdzie w zasadzie ściśle nie sprecyzowanej), por. np. VL, t. II, s. 252, fol. 1209.

${ }^{10}$ W. Uruszczak, Sejm walny Koronny w latach 1506-1540, Warszawa 1980, s. 127. 
go publicznego dokonywali bowiem w Rzeczypospolitej uprawnieni przedstawiciele państwa (np. członkowie wyznaczonej do prowadzenia negocjacji deputacji), ale ostateczne przyjęcie traktatu zależało od uchwały sejmu, publikowanej pod wspólnym tytułem i arengą sejmowych konstytucji. Sejm mógł traktatu nie ratyfikować i podówczas nie wchodził on w życie, w zasadzie nie wywołując skutków prawnych ${ }^{11}$. Potwierdza tę opinię świadectwo W. Skrzetuskiego, który wyraźnie podkreśla, że umowy międzynarodowe „w Konstytucye Seymowe wpisywano"12. Podobnie G. Lengnich, który używa zamiennie sformułowań: „pokazanie się przepisu przymierza w konstytucjach”, „potwierdzenie na Seymie” „potwierdzenie Prawem Pospolitym przez Sejm”13. Analogiczne wnioski trzeba wysnuć z innych świadectw źródłowych - zwłaszcza tekstów samych konstytucji „ratyfikacyjnych"14.

Kwestię niewątpliwie problematyczną stanowi klasyfikacja szerokiego katalogu, publikowanych wśród dorobku sejmów walnych, aktów szczególnego rodzaju. Na to zagadnienie trafnie zwrócił uwagę J. Seredyka, który wymienia w tym kontekście: dyplomy, asekuracje i informacje ${ }^{15}$. Oczywiście same w sobie stanowiły one akty odrębne i samoistne, ale one także były publikowane pod wspólnym tytułem konstytucji, często z dodatkowym opisem procedury zatwierdzenia uchwałą sejmową np. dokumentu wydanego wcześniej samodzielnie przez monarchę. Doskonałym przykładem może być tu słynna Assekuracya na odkrycie praktyk z sejmu 1607 r. Można by oczywiście upierać się, że ów akt, ze względu na wyodrębnienie redakcyjne, własny tytuł, arengę i for-

${ }^{11}$ Tak stało się, w okresie wykraczającym poza zakreślone przez nas ramy chronologiczne, z traktatem z Buczaczu z 1672 r., którego świadomie nie ratyfikowano na sejmie pacyfikacyjnym 1673 r. Autor monografii tego sejmu, podkreślając znaczenie faktu niepotwierdzenia traktatu przez sejm, słusznie podkreśla: „(...) przyjęcie przez komisarzy warunków traktatu pokojowego nie oznaczało jeszcze aprobaty tych postanowień przez Rzeczpospolita, albowiem wymagały one ratyfikowania ich przez sejm", L.A. Wierzbicki, O zgodę w Rzeczypospolitej. Zjazd warszawski i sejm pacyfikacyjny 1673 r., Lublin 2005, s. 239.

${ }^{12}$ Owszem, konstatacja ta odnosi się co prawda głównie do współczesnej autorowi praktyki osiemnastowiecznej, ale nie ma podstaw, żeby twierdzić, iż sytuacja ta kształtowała się odrębnie w okresach wcześniejszych, por. W. Skrzetuski, Prawo polityczne Narodu Polskiego, t. II, Warszawa 1784, s. 300, a także s. 306 i 318.

${ }^{13}$ G. Lengnich, Prawo pospolite Królestwa Polskiego, przetł. M. Moszczeński, Kraków 1761, t. I, s. $18,19,21$.

${ }^{14}$ Nie użyto w nich terminu ,konstytucja”, ale nie zostały też w żaden sposób wyodrębnione redakcyjnie. Formuły promulgacyjne zastosowane w potwierdzeniu rozejmu ze Szwecją w Altmarku (1629 r.) i pokoju z tym państwem w Sztumskiej Wsi (1635 r.), stwierdzały „aprobację” traktatów authoritate praesentis Conventus, por. VL, t. III, s. 310 fol. 647; s. 428, fol. 903.

${ }^{15}$ Należy w tym miejscu podkreślić, iż zupełnie innym problemem jest przykład „asekuracji królewskiej" wydanej poza sejmem, o której wspomina J. Seredyka, Sposób uchwalania, s. 33. Był to akt królewski, wydany w bardzo uroczystej formie, dotyczący egzekucji uchwały sejmowej, ale nie wolno jego wydania traktować jako czynności sejmowej i ustawodawczej, było to bowiem działanie pozasejmowe, a zatem akt królewski, nie wymagający zgody stanów sejmujących, wydany nie przez monarchę - rozumianego, jako stan sejmujący, ale przez monarchę - monokratyczny organ administracji publicznej. 
mułę promulgacyjną, jest uchwałą specyficzną. Jednakże umieszczono ją w takiej formie zaraz po zwyczajowej arendze całej konstytucji, zawierającej stałą formułe ,(...) na te wszystkie artykuły niżej opisane chętnie pozwalamy" 16 . Ponadto w tekście samej Assekuracyi... wyjaśniono jej charakter prawny za pomocą dość klarownej deklaracji: „A ten edykt seymową zgodą wszystkich stanów zawarty et in vim constitutionis promulgowany [podkr. T. K.] (...), zapieczętować, y po Grodziech bliższych rozesłać (...) rozkazaliśmy $(\ldots)^{17}$. Stwierdzenie, że jest to edykt, który zostaje promulgowany nie na mocy jakiejś odrębnej uchwały sejmu swoistego rodzaju, ale „w mocy konstytucji” sejmu 1607 r., oznacza, że co prawda, jako oddzielny akt monarszy (nazwany edyktem), wykazuje cechy autonomiczne, ale jego zatwierdzenie uchwałą trzech stanów sejmujących, oznacza formalne przyjęcie go w poczet (w moc) konstytucji sejmowej ${ }^{18}$.

W zakresie wspominanych przez S. Ochmann-Staniszewską i Z. Staniszewskiego uchwał organizacyjno-porządkowych, także trudno dostrzec jakiekolwiek cechy sugerujące odrębność tychże aktów od konstytucji sejmowych. Sprawa określenia podmiotu kompetentnego do „mianowania” senatorów rezydentów budzi poważne wątpliwości. Niestety, niezwykle istotna i dość skomplikowana materia instytucji rezydencji na dworze nie doczekała się dogłębnego i wyczerpującego studium, szczególnie w aspektach prawno-instytucjonalnych, stąd trudno o stawianie kategorycznych te ${ }^{19}$. Wiemy na pewno, iż nazwiska rezydentów publikowano z zasady w konstytucjach sejmów ordynaryjnych. Jednakże A. Nowakowski kategorycznie twierdzi, iż ich nominacji dokonywał samodzielnie król, bez udziału innych stanów, a na po-

${ }^{16}$ Por. VL, t. II, s. 432, fol. 1594.

${ }^{17}$ Por. VL, t. II, s. 432-433, fol. 1595-1596.

${ }^{18}$ Poprawnie, choć w nieco innym kontekście analizuje charakter omawianej konstytucji i kilku konstytucji podobnego rodzaju I. Lewandowska-Malec, op. cit., s. 549-550. Jeśli chodzi o inne akty wątpliwego charakteru prawnego, szczególnie ciekawy jest przypadek zamieszczonego wśród dorobku uchwałodawczego sejmu 1631 r. dyplomu o wolności elekcji (VL, t. III, s. 318-319, fol. 665-666). Naszym zdaniem, stanowi on swoisty aneks do konstytucji reasumuiącej dotychczasowe normy dotyczące nienaruszalności procedur elekcyjnych (por. Warunek wolney elekcyi, VL, t. III, s. 318, fol. 665). Monografista ostatnich sejmów odbytych za panowania Zygmunta III, J. Seredyka (Rzeczpospolita w ostatnich latach, s. 116 i n.) pisze w tym kontekście o „ogłoszeniu” dyplomu, co, jak słusznie zauważa, stanowić miało realizację wyraźnego nakazu jego publikacji, który na króla nałożyła konstytucja z 1607 r. Autor, koncentrując swoje uwagi na kwestiach politycznych, nie analizuje charakteru prawnego publikacji omawianego dokumentu w Voluminach Legum.

${ }^{19}$ Szczególnie dobitnym przykładem jest klasyczne wielotomowe wydawnictwo podręcznikowe pod redakcją J. Bardacha, w którym autor odnośnych ustępów, Z. Kaczmarczyk, na jednej stronie uznaje tu kompetencje sejmu, na następnej zaś wyłącznie króla, por. Historia państwa i prawa Pol$s k i$, t. II od połowy XV wieku do r. 1793, red. J. Bardach, Warszawa 1971, s. 126 i 127. Nawet w dogłębnym i rzetelnym studium o władzy wykonawczej w Polsce przedrozbiorowej, pióra D. Makiłły, sprawa powoływania rezydentów w ogóle nie została poruszona, por. D. Makiłła, Władza wykonawcza w Rzeczypospolitej: od połowy XVII wieku do 1763 roku. Studium historyczno-prawne, Toruń 2003, s. 133 i n. 
twierdzenie swej tezy przytacza potężny argument, mianowicie fakt powoływania przez króla rezydentów nawet $\mathrm{w}$ przypadku niedojścia sejmu ${ }^{20}$. Niezależnie od ostatecznego rozstrzygnięcia poruszanej kwestii (wymagającej bliższej i dogłębniejszej analizy), trudno byłoby wykazać, iż akt powołania rezydentów stanowił uchwałę sejmową, ale szczególnego rodzaju, niebędącą konstytucją sejmową. Jeśli, co przyznajemy bardziej do nas przemawia, senatorów rezydentów powoływał samodzielnie król, to nie była to w ogóle czynność sejmowa, a uprawnienie (jak określiłby to K. Grzybowski) „króla w parlamencie"21. Nawet jednak, jeśli uznać tu kompetencję sejmu, to nominacje na stanowiska senatorów rezydentów zamieszczano z zasady w jednej jednostce redakcyjnej z potwierdzeniem, uzupełnieniem bądź zmianą ogólnych reguł prawnych odnoszących się do omawianej instytucji, a tego dokonywano przecież wyłącznie w konstytucjach ${ }^{22}$. Sprawa jest już zupełnie oczywista w zakresie różnego rodzaju komisji wyznaczonych przez sejm i obdarzonych określonymi kompetencjami do załatwienia jakiejś sprawy. Nazwiska osób mających wejść w skład takich ciał kolegialnych publikowano bez wątpienia w ramach konstytucji, z zasady także wraz z uregulowaniem ich kompetencji ${ }^{23}$. Nie ma tu żadnego znaczenia, czy senatorowie i posłowie akceptowali tylko (nawet milcząco!) decyzje personalne króla bądź marszałka izby poselskiej, czy desy-

${ }^{20}$, „(...) nazwiska [rezydentów - T. K.] umieszczano odtąd w konstytucjach sejmowych (...). Taka procedura mogłaby prowadzić do domniemania, że nominacja rezydentów była poprzedzona uprzednią zgodą na ich powołanie ze strony pozostałych ,stanów sejmujących”. Jednak w rzeczywistości sejm nie miał żadnego wpływu na dobór rezydentów. Monarcha powoływał ich samodzielnie według kolejności zasiadania w senacie. Król zachowywał prawo nominacji rezydentów nawet w przypadku niedojścia sejmu do skutku, a nie było przypadku aby sejm kwestionował to (...) uprawnienie monarsze", A. Nowakowski, Senatorowie rezydenci w Polsce w latach 1573-1775, „Studia Historyczne”, R. XXXIV, 1991, z. 1, s. 25. Inaczej J. Byliński, który przyznaje w tym zakresie kompetencję wyłączną ... izbie poselskiej, J. Byliński, Dwa sejmy, s. 126.

${ }^{21}$ Istniało sporo form aktywności sejmowej, które nie były konstytucjami, a realizowały je samodzielnie poszczególne elementy konfiguracji instytucjonalnej, jaką był polski sejm, tzn. stany sejmujące. „Król w parlamencie” bez wpływu posłów i senatorów rozdawał np. „wakancje”. Wyroki sądu sejmowego, także nie były co oczywiste, zaliczane w poczet konstytucji sejmowych, a sądy wykonywał fizycznie jedynie król i senatorowie. Podobnie czynności samoorganizacyjne izby poselskiej - wybór marszałka, rugi poselskie, zgoda w kwestiach np. alternaty, czy naznaczenie deputatów do opracowania projektu konstytucji w określonej sprawy, odbywały się przy zachowaniu pełnej suwerenności izby. Omawiane czynności nie znajdowały odzwierciedlenia w publikowanych konstytucjach sejmowych.

${ }^{22} \mathrm{~W}$ omawianym okresie działo się tak na sejmach: 1607 r. (VL, t. II s. 433-434, fol. $1597-$ -1598); 1609 r. (VL, t. II, s. 463, fol. 1661-1662); 1613 (VL, t. III, s. 81, fol. 165); 1616 r. (VL, t. III, s. 133, fol. 272), 1618 r. (VL, t. III, s. 158-159, fol 327), 1619 r. (VL, t. III, s. 170, fol. 352); 1621 r. (VL, t. III, s. 186, fol. 384); 1623 r. (VL, t. III, s. 220, fol. 456); 1626 r. (VL, t. III, s. 240-241, fol. 500).

${ }^{23}$ Por. np. „Przychylaiąc się do dawnego prawa (...) naznaczyliśmy byli, za zgodą PP. Rad, y Posłów Ziemskich, uniwersałem naszym, y teraz tą konstytucyą [podkr. - T. K.] naznaczamy Deputaty do obierania kwarty(...)”, VL, t. II, s. 440, fol. 1612; bądź innych spraw („,z Seymu przeszłego konstytucyą na przeprawienie nowego portu do Królewca, zesłaliśmy [podkr. - T. K.] Kommissarzem Urodzonego Ianusza Skumina Tyszkiewicza (...)”, VL, t. III, s. 97, fol. 198. 
gnacja deputatów odbywała się w ramach zażartej dyskusji. Pamiętać przy tym trzeba, iż „głosowania” czy „wybierania”, w rozumieniu nam współczesnym podówczas właściwie w ogóle nie praktykowano ${ }^{24}$.

Jeśli spojrzymy na rezultaty działalności sejmowej z omawianego przez nas okresu, okaże się, iż jedyną formą zróżnicowania formalnego uchwał sejmowych był klasyczny podział na konstytucje i uniwersały poborowe ${ }^{25}$. Oba te akty przechodziły przez procedurę legislacyjną sejmu w zasadzie równolegle i uzyskiwały finalny kształt uchwał ${ }^{26}$. Uniwersały poborowe były oddzielone redakcyjnie od konstytucji uchwalonych na tym samym sejmie, posiadały odrębne uroczyste arengi, a wieńczyły je osobne solenne deklaracje o przyłożeniu pieczęci i przekazaniu do promulgacji na ,własne rozkazanie I.K.M."27. Taka formuła uniwersałów nie utrzymała się jednak nazbyt długo, w 1632 r. zrezygnowano z nich i poczęto „deklaracje” posłów województw i ziem dotyczące opodatkowania publikować wspólnie z innymi uchwałami, ze względu na jednolitość mocy prawnej i tożsamość podstawowych zasad procedury. Nie ulega zatem większej wątpliwości, że uchwały podatkowe niebędące uniwersałami, mimo pewnej specyfiki, należy ujmować w kategoriach konstytucji sejmowych. Takie postrzeganie tej problematyki znajduje swe uzasadnienie w źródłach $\mathrm{z}$ epoki oraz $\mathrm{w}$ ustaleniach literatury przedmiotu ${ }^{28}$.

${ }^{24}$ Oczywiście określenie sposobu desygnowania deputatów i rozstrzygnięcie związanych z tym wątpliwości budziło w izbie poselskiej częste kontrowersje. Na sejmie $1632 \mathrm{r}$. komisarzy ujętych w tekście konstytucji w rzeczywistości desygnowano dopiero po zamknięciu obrad i „dopisano” w ostatecznej fazie ucierania, por. J. Seredyka, Rzeczpospolita w ostatnich latach, s. 171.

${ }^{25}$ S. Grodziski, op. cit., s. 165, 170; I. Lewandowska-Malec, op. cit., s. 240.

${ }^{26}$ Ciekawie patrzy na omawiany problem I. Lewandowska-Malec (op. cit., s. 546), która opierając się na badaniach S. Estreichera, postrzega konstytucje jako „rodzaj uniwersału”, co potwierdzałoby tezę o głębokiej jednolitości tych aktów. Sprawa ta wymaga jednak głębszych badań, wykraczających poza merytoryczne i chronologiczne ramy niniejszego szkicu.

${ }^{27} \mathrm{~W}$ omawianym przez nas okresie historycznym uniwersały uchwalano na sejmach: $1607 \mathrm{r}$. (VL, t. II, s. 453-461, fol. 1639-1658); 1609 r. (VL, t. II, s. 475-478, fol. 1688-1694); 1611 r. (VL, t. III, s. 27-35, fol. 48-66); obu w r. 1613 (VL, t. III, s. 107-117 fol. 219-240; s. 123-132 fol. 252-271); 1616 r. (VL, t. III, s. 153-156, fol. 314-322); 1618 r. (VL, t. III, s. 159-169, fol. 329-348); 1619 r. (VL, t. III, s. 171-175; fol. 353-362); 1620 r. (VL, t. III, s.187-198, fol. 386-420); 1621 r. (VL, t. III, s. 209-215, 433-445); 1624 r. (VL, t. III, s. 226-235, fol. 470-488); obu w 1626 r. (VL, t. III, s. 241-250, fol. 500-521; s. 252-259; fol. 525-540); 1627 r. (VL, t. III, s. 266-276, fol. 554-575); 1628 r. (VL, t. III, s. 287-289; fol. 586-602) oraz 1629 r. (VL, t. III, s. 299-309, fol. 624-647) choć z uniwersałów zrezygnowano ostatecznie w 1632 r., kiedy uchwalono oddzielną konstytucję poborową (VL, t. III, s. 341-343, fol. 713-719; patrz także I. Lewandowska-Malec, op. cit., s. 241), to jeszcze na ostatnim sejmie panowania Władysława IV z roku 1647 odnajdujemy akt zatytułowany: Uniwersat y deklaracye o podatkach Rzpltey, tak Koronnych iako y W.X.Lit. na teraźniejszym Seymie pozwolonych, VL, t. IV, s. 70-72, fol. 140-144.

${ }^{28} \mathrm{~W}$ znakomitej, a zdaje się nieco zapomnianej monografii, problematykę ,deklaracji” podatkowych omówił dogłębnie Roman Rybarski. Niewątpliwie, ustanawianie podatków, pod względem konstrukcyjnym, przedmiotowym i podmiotowym, a także regulowanie taryf i stawek stanowiło kompetencję sejmu, formą wyłącznie właściwą były tu oczywiście konstytucje. Jednakże istotą systemu danin publicznych, był brak opodatkowania stałego. Konkretne uchwały podatkowe określonego sejmu, powołując się na ogólne konstrukcje podatkowe uchwalały jedynie kwotę pieniężną którą 
Po roku 1632 wszystkie akty finalne konkluzji sejmowej były w zasadzie publikowane pod wspólną uroczystą arengą w małych, oznaczonych tytułami wskazującymi na przedmiot regulacji, jednostkach redakcyjnych, bez żadnej stałej systematyki i wewnętrznych podziałów, sugerujących klasyfikację ze względu na charakter prawny bądź inne czynniki ${ }^{29}$. W tekstach tych redakcyj-

skarb miał uzyskać z określonej jednostki terytorialnej, a do władz tejże jednostki (czyli sejmików) należała repartycja obciążeń, pozwalająca taką kwotę uzyskać (można ją było określić za pomocą konkretnej sumy pieniędzy lub ilości „poborów” - czyli wielokrotności przychodów jednorazowych z podatku określonego rodzaju - najczęściej łanowego/ew. podymnego). Konstrukcyjnie zatem poszczególne sejmiki „deklarowały”, czy chcą podlegać opodatkowaniu, a następnie w jakiej wysokości. Słusznie profesor Rybarski zauważa, iż charakter deklaracji upodabniał je do swoistego „protokołu repartycji podatków”, który był jednakże „zamieszczony” w konstytucjach sejmowych (por. R. Rybarski, Skarb i pieniadz za Jana Kazimierza, Michała Korybuta i Jana III, Warszawa 1939, s. 79, całość rozważań dotyczących istoty i charakteru prawnego „deklaracji” podatkowych, s. 77-86). Owo ,zamieszczenie” w konstytucjach sejmowych trudno uznać za działanie przypadkowe, czy tylko techniczne. Było to bowiem , ustawowe” nałożenie na określone podmioty zobowiązania podatkowego, a sejmik, jako płatnik podatku, był zobowiązany do rozliczenia się z zadeklarowanych kwot. Zgoda powszechna stanów sejmujących i jednomyślność izby poselskiej, wyrażała się tu nie w przyjęciu jednolitego wymiaru określonego rodzaju podatku, ale na uznaniu i zaakceptowaniu konieczności wprowadzenia obciążeń. Wysokość podatków oraz określenie ich rodzaju (lub rodzajów) pozostawiano tu wiedzy i uczciwości przedstawicieli sejmików, którzy uzależniali je od wytycznych z poselskiej instrukcji opartej o ocenę potrzeb (np. zagrożenia wojennego, zaległości finansowych względem wojska itp.), możliwości płatniczych (urodzaju, wystąpienia klęsk żywiołowych, zniszczeń itp.), a także pozytywnej oceny polityki monarchy. Brak szczegółów technicznych, wskazówek egzekucyjnych, tzn. danych koniecznych administracji, stanowił cechę charakterystyczną dla wszystkich konstytucji tego okresu, nie tylko w sprawach podatkowych. Elastyczność stosowanych rozwiązań, ich „połowiczność” i kompromisowość, przy znacznym zróżnicowaniu środków przewidzianych względem poszczególnych województw i ziem, także nie stanowiły wyłącznego wyróżnika konstytucji z zakresu spraw podatkowych. Nie widzimy zatem podstaw, by deklaracje podatkowe, przy pełnym zrozumieniu dla ich specyfiki, traktować jako akt sejmowy szczególnego rodzaju nie będący konstytucją.

${ }^{29}$ Zdarzało się publikowanie w Zbiorze Praw takich aktów czy dokumentów, co do których „konstytucyjnego” charakteru można mieć pewne wątpliwości. Z taką sytuacją mieliśmy do czynienia na sejmie 1611 r., gdzie po tekście uniwersału poborowego zamieszczono zupełnie oddzielnie akt poświęcony sądowemu postępowaniu w sprawach karnych: Postępek prawny skrócony (nie posiadał arengi, po tytule dodano jedynie imię i tytulaturę króla Zygmunta III, kończy go zaś formuła „,na rozkazanie króla I.M.”), por. VL, t. III, s. 35-43, fol. 67-86, a także zestaw aktów związanych z oddaniem lenna pruskiego linii brandenburskiej Hohenzollernów, zwieńczone wskazaniami podpisów króla i Hieronima Cieleckiego, por. VL t. III, s. 44-80, fol. 86-162. Niestety monografista sejmu $1611 \mathrm{r}$. nie zajmuje się bliżej kwestią wskazanych aktów i ich charakteru prawnego, ale opierając się na bogatym materiale źródłowym, używa względem nich konsekwentnie określenia „konstytucja”, por. J. Byliński, Sejm z roku 1611, s. 186 i 201. Wyodrębnienie graficzne omawianych aktów wynikało raczej z ich obszerności i integralności, miało więc wprowadzić nieco więcej ładu w układzie treści uchwał sejmowych, a nie eksponować ich odrębność prawną. Podobnie na sejmie 1613 roku wyodrębniono pakta zawarte z cesarzem, por. VL, t. III, s. 102-107, fol. 209-218. Monografista tegoż sejmu, J. Byliński, stwierdził, iż tekst tych paktów został „włączony do konstytucji” sejmowej, por. J. Byliński, Dwa sejmy, s. 129. Wśród dorobku uchwałodawczego sejmu 1643 r. znajdujemy sprawozdanie z prac komisji w sprawach skarbowych i podatkowych: Kommissya de pretiis rerum et inductis (VL, t. IV, s. 39-41, fol. 74-80), a także stosowny Instruktarz (VL, t. IV, s. 42-43, fol. 80-83). Członkowie komisji podkreślają, iż zostali „konstytucyą blisko przeszłego Seymu od Rzeczypospo- 
nie wyodrębnionych części składowych formalnej całości tworzonej przez ogół uchwał sejmowych, nie podkreślano raczej ich charakteru jako „konstytucji". Wspominano o tym tylko niekiedy, jeśli użycie nazwy było konieczne dla gramatycznej i logicznej spójności tekstu. Używano podówczas zamiennie pojęć: „konstytucja” i „,uchwała” bądź innych wyrażeń synonimicznych ${ }^{30}$. Wynikało to z dość oczywistego faktu nieprzykładania większej wagi przez szlacheckich obywateli Rzeczypospolitej (nawet tych biorących czynny udział w życiu politycznym państwa czy odgrywających w tym procesie pierwszoplanowe role) do kwestii formalnoprawnych i teoretycznoprawnych w procesie stanowienia prawa, jego egzekwowania, a także ujmowania tych zjawisk w ramy terminologiczne w czasie dyskusji sejmowych albo publicystycznych. Naszym zdaniem ówczesna praktyka prawodawcza opierała się raczej na rozumieniu prawa przez pryzmat trzech zasadniczych czynników:

1) abstrakcyjnych wartości etycznych, uświęconych tradycją „przodków”31;

2) okoliczności politycznych, czyli z jednej strony, wymogów negocjacji związanych z osiaganiem ,zgody” (rozumianej nie jako prosta suma wszystkich jednomyślnych głosów, ale jako osiagnnięcie kompromisowego stanowiska gwarantującego powszechną akceptowalność określonego rozwiązania prawnego ${ }^{32}$ oraz z drugiej strony, standardów potrzeby lub użyteczności publicznej (necessitas et utilitas publica) ${ }^{33}$;

3) intuicyjnego wyczuwania istnienia i kształtu instytucji prawnych ${ }^{34}$.

litey naznaczeni”, co w zestawieniu z datą jej prac (po zakończeniu sejmu), sugeruje, że jest to forma specyficznego aneksu do konstytucji podatkowych.

${ }^{30}$ I. Lewandowska-Malec wymienia w omawianym kontekście określenia: ,artykuły”, a także „,sprawy” i ,rzeczy”, por. I. Lewandowska-Malec, op. cit., s. 549. Osobiście dodalibyśmy tutaj także słowo „punkty”, a także po prostu ,prawo”. Warto podkreślić częste stosowanie formuł opisowych, zamiast bowiem pisać o uchwaleniu w jakieś kwestii konstytucji, pisano o uregulowaniu jakiegoś zagadnienia „mocą niniejszego sejmu za zgodą trzech stanów” itp.

${ }^{31}$ Nie ulega wątpliwości, że prawo pisane omawianego okresu, wbrew stanowisku współczesnemu, opartemu na schematach intelektualnych pozytywizmu prawniczego, ustępować musiało przed Prawem Bożym, wyznaczającym standardy powszechnie przyjętych zasad moralnych oraz uświęconym zwyczajem. Nad wyraz trafnie eksponuje rolę naturalnego prawa bożego w systemie prawnym dawnego państwa polskiego W. Uruszczak, w swej najnowszej syntezie dziejów ustroju i prawa Polski, por. W. Uruszczak, Historia państwa i prawa polskiego, t. I (966-1795), Warszawa 2010, s. 221-222.

${ }^{32}$ Dość jednostronne i jednoznacznie pejoratywne podejście do kwestii zasady „zgody” uległo w literaturze przedmiotu pewnej modyfikacji, por. zwłaszcza K. Grzybowski, op. cit., s. 273-317 oraz D. Roháč, The unanimity rule and religious fractionalisation in the Polish-Lithuanian Republic, „Constitutional Polical Economy”, vol. 19, nr 2, s. 111-128. Sprawa zasady zgody oraz jej praktycznej konsekwencji w postaci liberum veto wymaga jednak dalszych badań, jako jeden z najistotniejszych elementów ustrojowych i fenomenów kultury prawnej społeczeństwa staropolskiego.

${ }^{33} \mathrm{O}$ tym elemencie wspomina słusznie w kontekście swoich rozważań odnośnie do funkcjonowania reguły lex retro non agit $\mathrm{w}$ staropolskim porządku prawnym, H. Grajewski, op. cit., s. 49. Warto podkreślić, iż ma to związek z zasadą panującą w europejskiej kulturze prawnej od czasów starożytnego Rzymu, według której necessitas omnem legem frangit.

${ }^{34}$ Rzadko zwraca się uwagę na omawiany problem w literaturze przedmiotu, a przecież brak rozwiniętej nauki teorii prawa oraz niechęć do ujęć dogmatycznych w nauce ustrojowej przy nakie- 
Reasumując ten etap naszych rozważań, należy stwierdzić, iż brakuje podstaw źródłowych do stwierdzenia istnienia zróżnicowania uchwał sejmowych ze względu na ich moc prawną, materię regulowaną, formę gramatyczną czy redakcyjną albo niuanse proceduralne związane z ich przyjmowaniem. Dla szlacheckiej opinii publicznej nie miało znaczenia, czy sejm uchwalił projekt przygotowany przez posłów, czy zaakceptował wcześniej wydany dokument króla (legalny bądź nie!), czy też potwierdził zawarty traktat międzynarodowy. Podobnie, pozbawiony istotnych konsekwencji w tej mierze był fakt, czy dana konstytucja była uchwalaniem określonej normy prawnej, deklaracją podatkową województw i ziem, czy akceptacją desygnacji deputatów, dokonaną chociażby przez marszałka izby poselskiej. Ważne, iż dane rozwiązanie, uzyskawszy aprobatę trzech sejmujących stanów, zostało bez sprzeciwów zaakceptowane w konkluzji niezerwanego sejmu, po czym przeszedłszy procedurę „ucierania”, zostało prawidłowo opieczętowane i opublikowane. Dlatego właśnie fakt ujmowania konstytucji sejmowych jako specyficznych aktów o określonych cechach dystynktywnych, które można odróżnić od innych rezultatów obrad sejmowych, nie tylko nie ma solidnej podbudowy źródłowej, ale dodatkowo wprowadza niepotrzebny zamęt, którego egzemplifikację stanowi różnorodność teorii wskazanych powyżej i ich wzajemna niekompatybilność. Na potrzeby niniejszego szkicu zaryzykujemy zatem tezę, iż każdy akt uchwalony przez sejm w drodze ,zgody” wszystkich trzech stanów, a przy tym prawidłowo opublikowany i opieczętowany, na przestrzeni okresu XVI-XVIII w., był konstytucją sejmową ${ }^{35}$.

rowaniu na rozwiązywanie przez ustawodawcę konkretnych problemów w konkretnych okolicznościach, nie wyklucza istnienia abstrakcyjnych zasad, czy uniwersalnych konstrukcji prawnych, które trzeba z zasady wyinterpretowywać i rekonstruować z norm staropolskiego prawa. Takie działanie, z dużym powodzeniem podją ostatnio w tworzeniu katalogu podstawowych zasad ustrojowych Rzeczypospolitej, W. Uruszczak, Zasady ustrojowe Rzeczypospolitej Obojga Narodów, „Czasopismo Prawno-Historyczne”, t. LX, 2008, z. 2, s. 125-156 oraz idem, Historia państwa, s. 188-221.

${ }^{35}$ Koresponduje to z uwagami źródłowymi W. Skrzetuskiego, który wymieniając podstawowe źródła polskiego prawa pospolitego, wskazuje tylko sejmowe konstytucje, utożsamiając je z wcześniejszymi statutami. Odróżnia od nich jedynie pacta conventa, jako źródło specyficzne, por. W. Skrzetuski, op. cit., s. 5-12. Należy tu zwrócić uwagę na odrębność nie tylko paktów konwentów, ale w ogóle uchwał sejmów okresu bezkrólewia (odbywanych bez monarchy): konwokacyjnego (gdzie uchwalano tylko akt konfederacji generalnej, por. VL, t. III, s. 345, fol. 723; t. IV, s. 74, fol. 148; s. 482; fol. 1025) oraz elekcyjnego (gdzie uchwały tytułowano „Aktami sejmu”, por. VL, t. III, s. 358. fol. 753; t. IV, s. 87, fol. 180; t. V, s. 5, fol. 1). Zupełnie odrębny, a niezbadany dogłębnie charakter miały niepublikowane w Voluminach Legum, Akty konfederacji generalnych oraz sancitia konfederackie (wydawane przez Zjazd Generalny bądź Walną Radę), z konfederacji generalnych koronnych okresu panowania króla. Jest to jednak problematyka wykraczająca merytorycznie i chronologicznie poza ramy niniejszego opracowania, warto w tym zakresie odwołać do znakomitej pracy W. Stanka, Konfederacje generalne koronne w XVIII wieku, Toruń 1991, s. 39-55, 65-79, 95-97. Istotną wątpliwość można żywić odnośnie charakteru prawnego skryptów ad archiwum, które ze swej definicji nie miały być poddane procedurze oficjalnej publikacji. A Rachuba w pracy Wielkie Księstwo Litewskie w systemie parlamentarnym Rzeczypospolitej w latach 1569-1763, Warszawa 2002, s. 180, przyjął, iż nie były one konstytucjami sejmowymi. Problem z oceną prawnego charak- 
II. Charakter prawny konstytucji sejmowych. Teza o jednolitej mocy prawnej i formie uchwał sejmowych (ujmowanych w kategoriach konstytucji sejmowej) nie wyklucza ich wewnętrznego zróżnicowania i to nie tylko pod względem zakresu przedmiotowego zawartej w nich regulacji, ale także z uwagi na inne kryteria. Szeroki wachlarz zadań i kompetencji przedrozbiorowego sejmu walnego powodował, że zarówno treść, jak i forma „ustawodawstwa” polskiego tego czasu wykracza poza ramy charakterystyczne dla uprawnień parlamentów współczesnych demokracji. Mimo licznych sporów na tle wyodrębnienia kryteriów wewnętrznych klasyfikacji konstytucji sejmowych, możemy stwierdzić, iż podstawowe znaczenie odgrywają:

1) zakres terytorialny ich obowiązywania (konstytucje generalne/ogólnopolskie i terytorialne/prowincjonalne) ${ }^{36}$;

2) zakres podmiotowy (publiczne i prywatne) ${ }^{37}$;

3) zakres czasowy obowiązywania (wieczyste i temporalne) $)^{38}$;

4) jawność (publikowane i skrypty ad archivum) ${ }^{39}$;

5) zakres przedmiotowy ${ }^{40}$

6) charakter prawny.

Szczególnie ostatnie z podanych kryteriów ma wyjątkowe znaczenie dla nauki historii prawa, budzi zresztą największe kontrowersje w literaturze przedmiotu. Nie wchodząc głęboko w istniejące spory (nie pozwalają na to niewielkie rozmiary niniejszego szkicu), w nawiązaniu także do wniosków z rozważań powyższych, pragniemy stwierdzić, iż naszym zdaniem konstytucje sejmowe możemy ze względu na charakter prawny podzielić na:

teru skryptów jest bardzo skomplikowany, przez długi czas bowiem, szlachecka opinia publiczna uważała je za całkowicie nielegalne. Przygotowywano je raczej niechętnie i ,pokątnymi” metodami, co nie sprzyjało zdefiniowaniu i dookreśleniu ich cech dystynktywnych. Nie ulega jednak wattpliwości, że publikowano wzmianki o nich (czy też może upoważnienia do ich spisania, albo publikowane stwierdzenie ich obowiązywania?) w Zbiorze Praw, z podkreślaniem uzyskania zgody na nie, ze strony wszystkich trzech sejmujących stanów. Były one zatem na pewno konstytucjami w sensie formalnym, choć sprawa ta wymaga dalszych badań.

${ }^{36}$ Por. I. Lewandowska-Malec, op. cit., s. 576-577.

${ }^{37}$ Podział ten wprowadzony został przez prof. J. Seredykę (Sejm z 1618 roku, s. 185) i przez wiele lat nie budził w zasadzie kontrowersji w literaturze przedmiotu, jego zasadność potwierdziła ostatnio I. Lewandowska-Malec, op. cit., s. 243-246. W recenzji tejże książki zakwestionował go wszelako H. Olszewski, Sejm walny koronny Rzeczypospolitej Obojga Narodów i jego dorobek ustawodawczy, „Czasopismo Prawno-Historyczne”, t. LXIII, 2011, z. 1, recenzje i noty recenzyjne, s. 504-507. Nie wchodząc w meritum sporu wybitnych badaczy, należy podkreślić, iż istnienie tego podziału znajduje odzwierciedlenie w relacjach źródłowych, szczególnie w diariuszach sejmowych. Kwestią sporną wydaje się jedynie realny charakter konstytucji prywatnych i zakres ich stosowania.

${ }^{38} \mathrm{Na}$ ten temat por. zwłaszcza bardzo interesujące uwagi H. Grajewskiego, op. cit., s. 13-17.

${ }^{39}$ I. Lewandowska- Malec, op. cit., s. 246 i n.

${ }^{40}$ Klasyfikacje sfer kompetencji sejmu, wyznaczających kategorie przedmiotowe konstytucji są przeróżnie definiowane w literaturze, por. zwłaszcza: dla okresu po roku konstytucji Nihil novi, W. Uruszczak, Sejm walny koronny w latach 1506-1540, Warszawa 1980, s. 127-147; dla okresu omawianego przez nas w niniejszym szkicu, I. Lewandowska-Malec, op. cit., s. 257-400. Patrz także standardowe ujęcie w systemie: Historia państwa i prawa..., t. II, red. J. Bardach, s. 126-127. 
1) konstytucje w sensie ścisłym, inaczej nowelizujące, tzn. tworzone w celu wykreowania nowego stanu prawnego (wśród nich możemy wymienić konstytucje: a) zawieszające moc norm prawa pospolitego; b) zmieniające obowiązujące normy prawa pospolitego; c) wprowadzające do systemu prawa pospolitego normy wcześniej nieznane; d) uchwalające („deklarujące”) podat$\mathrm{ki}$; e) ratyfikujące traktaty międzynarodowe);

2) konstytucje egzorbitancyjne, tzn. tworzone w celu przywiedzenia do egzekucji nieprzestrzeganego prawa (wśród nich możemy wskazać: a) potwierdzające obowiązujące normy; b) „objaśniające obowiązujące normy; c) wpływające na sytuację prawną określonych podmiotów, bądź grup podmiotów, uchylające względem nich decyzje organów administracji, bądź wyroki sądów, wydane z pogwałceniem powszechnie obowiązujących norm prawa pospolitego);

3) konstytucje administracyjne (w tej kategorii możemy wyodrębnić konstytucje: a) nakładające obowiązek wykonania planu; b) tworzące uprawnienia lub obowiązki dla określonego adresata, bądź grupy adresatów);

4) konstytucje proceduralne (przede wszystkim: a) recesy, a także b) upoważnienia do zwołania sejmów ekstraordynaryjnych).

Wyżej zarysowany podział został oparty na ustaleniach W. Uruszczaka, które uważamy za najtrafniejsze spośród wszystkich pojawiających się w literaturze przedmiotu ${ }^{41}$. Wprowadziliśmy doń jednak kilka istotnych modyfikacji, które wymagają szerszego uzasadnienia.

Konstytucje w sensie ścisłym (nowelizujące), czyli tzw. „nowe prawa”, zgodnie z konstytucją Nihil novi musiały być uchwalone zgodnie przez trzy stany sejmujące. Stanowiły one kategorię najbardziej zbliżoną do dzisiejszych ustaw. Ich istota sprowadzała się w zasadzie do wprowadzania zmian w obowiązującym prawie pospolitym (ius communae). W omawianym przez nas okresie objawiało się to przede wszystkim w użyciu różnych odmian czasowników: „deklarować”, „postanawiać”, rzadziej „rozkazywać”42. Oczywistym jest, że takie konstytucje mogły zawieszać i zmieniać obowiązując normy prawne, a także wprowadzać nowe, nieznane wcześniej rozwiązania ${ }^{43}$. Do tej właśnie kategorii konstytucji zaliczyliśmy jednak także wspomniane już konstytucje podatkowe z okresu po 1632 r. „Nowymi prawami” były też naszym

${ }^{41}$ Według tego autora konstytucje należy dzielić na: 1) nowelizujące prawo pospolite (zawieszające lub zmieniające prawo pospolite, ew. rozszerzające je o nowe przepisy); 2) potwierdzające lub powtarzające dotychczasowe normy; 3) uchwały w sprawie wykonywania obowiązujących praw (o charakterze zbliżonym do rozporządzeń wykonawczych); 4) zarządzenia administracyjne, por. W. Uruszczak, Sejm walny koronny, s. 138.

${ }^{42}$ Szeroki katalog egzemplifikacyjny sformułowań pełniących omawianą funkcję prezentuje I. Lewandowska-Malec, op. cit., s. 568-569. Autorka umieszcza tu zarówno formuły przepisów nowelizujących (wprowadzających nowe prawa), jak i „objaśniających” (którymi zajmiemy się bliżej w części V niniejszego szkicu).

${ }^{43}$ W. Uruszczak, Sejm walny koronny, s. 138. 
zdaniem, o czym już wspominaliśmy, uchwały sejmowe w zakresie potwierdzania traktatów międzynarodowych, mimo używania w nich formuły „rasumpcji”44.

Kategoria konstytucji wymieniona w punkcie 3 wynikała z oczywistego faktu, że sejm ówczesny był także, przynajmniej w pewnym sensie, organem administracji publicznej ${ }^{45}$. Nasze wątpliwości budzi nazewnictwo, używany dość powszechnie termin ,zarządzenie”, ze względu na konotacje ze współczesnym systemem prawnym wydaje się raczej niefortunny, stąd postanowiliśmy go zmienić na ogólnikową frazę ,,konstytucje administracyjne”. Mogły one nakładać na określone organy państwa obowiązek wykonania jakiegoś planu (podobnie jak dzisiejsze administracyjne akty planowania), dotyczyło to najczęściej przedsięwzięć infrastrukturalnych (dziś to organy administracyjne przygotowują takie plany $\mathrm{w}$ oparciu o przegłosowany $\mathrm{w}$ parlamencie budżet $)^{46}$, zwiększenia autoramentu określonego rodzaju jednostek wojskowych $^{47}$, a także szczegółowych planów kampanii wojennych (dziś nie stanowią przedmiotu debat sejmowych, ale są opracowywane przez wyspecjalizo-

${ }^{44}$ Zaakceptowanie przez sejm traktatu międzynarodowego, mimo użycia w nich formuły prawnej ,,reasumpcji”, miało niewątpliwie inny wymiar niż potwierdzanie obowiązujących już konstytucji i odpowiadało w zasadzie współczesnej procedurze ratyfikacji, będąc koniecznym warunkiem do włączenia ustaleń aktu umownego prawa międzynarodowego publicznego, w zakres systemu powszechnie obowiązującego prawa Rzeczypospolitej. Warto podkreślić, iż szlachecka opinia publiczna uważała technikę reasumpcji za adekwatną dla ratyfikacji traktatów międzynarodowych, zdając sobie przy tym sprawę z jej odrębnego konstytutywnego charakteru, szczególnie ciekawą jest tu relacja negocjatora pokojowego ze Szwecją w latach dwudziestych XVII w., J. Tyszkiewicza, który cytuje liczne wyciagi z korespondencji, przekazując szerokie spektrum, dość jednolitych w swej treści poglądów por. Umowy ze Szwecyja. Dyariusz Janusza Tyszkiewicza z r. 1625, [w:] Biblioteka starożytna pisarzy polskich, wyd. K. Wł. Wojcicki, t. V, Warszawa 1854, s. 21, 27-28.

${ }^{45}$ Niewątpliwie w staropolskiej kulturze prawnej rozróżniano działalność w sensie ścisłym legislacyjną od administrowania; klarownie wyraża to myśl publicysty z połowy XVII w., według której: „między przestrzeganiem starego prawa a między ferowaniem nowego, powinna być dyferencyja”, Dyskurs o eksorbitancjach, [w:] Pisma polityczne z czasów panowania Jana Kazimierza Wazy 1648-1668 r., wyd. S. Ochmann-Staniszewska, Wrocław/Warszawa 1991, t. III, s. 337. Jednakże skupienie obu tych funkcji w konstytutywnych kompetencjach sejmu, także nie ulegało wątpliwości już dla ówczesnych obserwatorów, mocno podkreśla ten fakt między innymi J.J. Rousseau, Uwagi o rzqdzie polskim, [w:] J. J. Rousseau, Umowa społeczna oraz; Uwagi o rzadzie polskim; Przedmowa do „Narcyza”, List o widowiskach; List o opatrzności; Listy moralne; List do arcybiskupa de Beaumont; Listy do Malesherbesa, wyd. B. Baczko, Warszawa 1966, s. 240-241.

${ }^{46}$ Ciekawe świadectwo stanowią tu konstytucje dotyczące problemu restaurowania twierdz. Wg tekstu jednej z nich: „Za wątłemi fundamentami structura zamku Lubelskiego vetustate consumpta, po niemałey części iuż upaść musiała, przeto naznaczamy Rewizory nasze (...) na uznanie restauracyi y edyfikacyi zamku tego. Co potym na przyszłym da Pan Bóg Seymie dla uznania y naznaczenia kosztu na restauracyą zamku tego do decyzyi Nam y Stanom Koronnym podać maią, VL, t. III, s. 334, fol. 669. Co interesujące istniały w ówczesnej Rzeczypospolitej zalążki partnerstwa publiczno-prawnego w tego typu sprawach - por. aprobację przez sejm umowy o naprawę i dzierżawę ekonomii rogozińskiej, VL, t. III, s. 389 fol. 820-821.

${ }^{47} \mathrm{Tu}$ np. konstytucje dotyczące organizacji pospolitego ruszenia (por. np. VL, t. III, s. 198-204, fol. 110-122), czy wojska zaporoskiego (por. np. VL, t. III, s. 122, fol. 249-250). 
wane sztaby $)^{48}$. Konstytucje administracyjne mogły ponadto decydować o uprawnieniach bądź obowiązkach określonych podmiotów lub ich grup, zarówno decydując o trwałym statusie osoby (np. nadanie szlachectwa) ${ }^{49}$, jak i nakładając na określone podmioty lub grupę podmiotów obowiązek spełnienia na rzecz państwa określonych świadczeń osobistych lub rzeczowych ${ }^{50}$. Konstytucjami administracyjnymi rozpatrywano często konkretne i indywidualne sprawy jakiegoś podmiotu, w zakresie wynagrodzenia jego zasług, kompensacji prywatnych kosztów poniesionych na rzecz, czy w służbie państwowej $^{51}$. Co w tym kontekście szczególnie interesujące, konstytucje sejmowe nadawały podmiotom prywatnym możliwość wykonywania pewnych uprawnień przynależnych organom administracyjnym (wraz z możliwością czerpania $z$ nich korzyści $)^{52}$. Sejm za pomocą konstytucji administracyjnych mógł przyznawać zwolnienia podatkowe dla płatników podatku (poborców) ${ }^{53}$.

Ponadto przydajemy w tym miejscu także dodatkową odmianę konstytucji, w postaci sejmowych uchwał proceduralnych. Należą tu przede wszystkim recesy sejmowe - uznajemy w pełni zasadność konstatacji o przyjmowaniu przez nie formy uchwały sejmowej i takiejże mocy wiążącej. Jak już wspominaliśmy, publikowanie ich pod wspólną arengą oraz brak wyszczególnienia redakcyjnego czy zaznaczenia odrębnej mocy prawnej nie upoważnia do uznawania ich za uchwałę szczególnego rodzaju ${ }^{54}$. Naszym zdaniem, do tej samej

${ }^{48}$ Taki charakter miały także oczywiście niepublikowane skrypty ad archivum.

${ }^{49}$ Najczęściej dokonywane w formie potwierdzenia przywileju na szlachectwo, wydanego uprzednio przez króla: „Przywiley od Nas Stanisławowi Przytyckiemu na tym Seymie na szlachectwo dany authoritate praesen. Conventus, in toto approbuiemy”, VL, t. III, s. 94, fol. 193.

${ }^{50}$ Por. np. „Iż zamek Możerski po zgorzeniu, dotąd ieszcze zbudowany nie iest (...) wkładamy to na wszystkie poddane nasze, którzy teraz do zamku Możerskiego należą, y co też różne osoby stanu szlacheckiego, prawem dożywotnym od tego Starostwa Możerskiego trzymaią; także y na mieszczany Możerskie, którzy wszyscy według powinności dawney (...) zamek iak nayprędzey budować zacząwszy, nie ustaiąc dokonali (...)", VL, t. III, s. 26, fol. 47.

${ }^{51}$ Patrz np. „Pokazało się z liczby Wielmożnego Iarosza Wołłowicza, Podkanclerzego Ziemskiego, iż on zabiegaiąc gwałtownym potrzebom Rzpltey, u różnych osób pieniędzy dostawaiąc, dłużyć się musiał (...) którey summy zapłatę ukazuiemy (...)”, VL, t. III, s. 159, fol. 327.

52, ,...) za spólną zgodą wszystkich Stanów Koronnych, pozwalamy Urodzonemu Stanisławowi Wapowskiemu, Kasztellanowi Przemysłskiemu, składu winnego czasy wiecznemi do miasteczka iego dziedzicznego Dynowa (...)", VL, t. III, s. 19, fol. 31.

${ }^{53}$ Por. np. „Iż za turbacyą i włokitami swawoleństwa Kozackiego od Łobody y Nalewayka w roku przeszłym 1593 y szóstym, Poborca Powiatu Możerskiego Kupryan Oskierka, poboru tak łanowego dla rozeszcia chłopów (...) od szlachty, ani spławnego y szosowego wybrać od kupców nie mógł, o co iuż (...) mandatem naszym pozwany był (...) za pokazaniem listu (...) od obywatelów tamtych kraiów, że tego prawdziwie dobrać nie mógł, teraz za prośbą PP. Oboyga narodu (...) Poborcy przysięge, iako tego poboru sprawiedliwie dla turbacyi wybrać nie mógł nakazuiemy: którą wykonać (...) powinien będzie. A po wykonaniu przysięgi tę resztę z niego znosimy (...)”, VL, t. III, s. 26, fol. 46.

${ }^{54}$ Tak I. Lewandowska-Malec, op. cit., s. 251-253. W omawianym okresie na kartach Voluminów Legum możemy odnaleźć sporo konstytucji zatytułowanych jako recesy (por. VL, t. III, s. 159, fol. 328; s. 171, fol. 353, s. 186, fol. 384, s. 226, fol. 469, t. IV s. 46, fol. 89). Co jednak istotne, a rzadko zauważane na kartach literatury przedmiotu, recesy mogły także być publikowane w innych miej- 
grupy konstytucji należy jeszcze zaliczyć wydawane przez sejm upoważnienia do zwołania sejmów nadzwyczajnych ${ }^{55}$.

Zasadniczą modyfikacją względem teorii prof. Uruszczaka zastosowaną w wyżej zaprezentowanym schemacie, jest wyodrębnienie przez nas kategorii „konstytucji egzorbitancyjnych”, którym poświęcimy pozostałą część niniejszych rozważań.

\section{Ogólna charakterystyka konstytucji egzorbitancyjnych. Wyodręb-} nienie konstytucji egzorbitancyjnych wymaga uzasadnienia, które musi się oprzeć na doprecyzowaniu ich istotnych cech dystynktywnych. Przede wszystkim należy podkreślić fakt, iż funkcją omawianej grup konstytucji sejmowych była „naprawa” egzorbitancyjnych naruszeń prawa, wykonywana przez sejm w ramach jego uprawnień kontrolnych względem wszystkich organów pań$\mathrm{stwa}^{56}$. Stwierdzenie nieskuteczności określonych reguł prawnych rodziło reakcję legislacyjną sejmu, której celem była nie zmiana, a zachowanie obowiązującego stanu prawnego ${ }^{57}$. Jak już wspominaliśmy, naszym zdaniem konstytucje egzorbitancyjne składały się z trzech kategorii norm. Za ich pomocą sejm walny mógł dokonywać, po pierwsze, powtarzania i potwierdzania obowiązywania konstytucji, po drugie, uzupełniania ich o przepisy wykonawcze (czy też dokonywania ich autentycznej wykładni) ${ }^{58}$, a po trzecie, wpływa-

scach (z zasady umieszczano je na samym końcu, jako ostatnią bądź jedną z ostatnich jednostek redakcyjnych dorobku sejmowego) dotyczyć odłożenia nie ogółu abstrakcyjnie ujmowanych, a nierozpatrzonych na sejmie spraw, ale kwestii konkretnej i określonej, patrz np. „Composito inter status, iż na tym Seymie dla wielu wielkich y ważnych spraw doyść nie mogła: tedy authoritate Conventus praesentis, do drugiego blisko przeszlego Seymu odkladamy [podkr. - T. K.], VL, t. III, s. 159 , fol. 325 .

${ }^{55}$ Por. VL, t. III, s. 215-216, fol. 447-448; s. 237, fol. 492-493; s. 259-260, fol. 541; s. 294, fol. 612; s. 326, fol. 81, s. 373, fol. 786; s. 413, fol. 870-871; VL, t. IV, s. 9-10, fol. 10-11; s. 46, fol. 89-90. O konstytucjach upoważniających do zwołania sejmu nadzwyczajnego patrz również P. Paradowski, op. cit., s. 19-41.

${ }^{56}$ Egzorbitancje ujmowane w kategoriach instytucji prawnej nie budziły dotąd szczególnego zainteresowania w literaturze przedmiotu. Definiujemy to zjawisko jako zarzuty formułowane przez głównie szlachecką opinię publiczną, przeciwko działaniom lub zaniechaniom w funkcjonowaniu instytucji, o pozycji ustrojowej wtórnej wobec form szlacheckiej demokracji bezpośredniej (zwłaszcza sejmu, organów władzy wykonawczej oraz sądów), dotyczące łamania przez te organy praw indywidualnych i zbiorowych szlachty. Na kanwie owych postulatów wdrażano proces legislacyjny, mający doprowadzić do uchwalenia aktów imperatywnych o randze konstytucji sejmowych, które stanowiły deklaratoryjne potwierdzenie obowiązującego prawa.

${ }^{57}$ Jest to nad wyraz ciekawe zjawisko w dziejach przdrozbiorowej polskiej legislacji i kultury prawnej polskiej szlachty. G. Lengnich zauważał, iż konstytucjami sejmowymi w przedrozbiorowej Polsce „dawne prawa bywają stwierdzane albo nowe stanowione”, G. Lengnich, op. cit., s. 5. Trafnie ocenia to zjawisko H. Olszewski, kiedy konstatuje, iż: „intencją ustawodawców było w znacznie większym stopniu utrzymanie obowiązującego prawa aniżeli jego zmienianie (...)”, H. Olszewski, op. cit., s. 392.

${ }^{58}$ Oddzielenie przez prof. Uruszczaka potwierdzania bądź powtarzania konstytucji, od zjawiska ich uzupełniania (ewentualnie dokonywania ich autentycznej wykładni) poprzez uczynienie z nich 
nia na sytuację prawną określonych podmiotów (bądź grupy podmiotów) poprzez uchylanie względem nich decyzji organów administracji i wyroków sądów, wydanych z pogwałceniem powszechnie obowiązujących norm prawa pospolitego. Wzmianki o konstytucjach z tej grupy rzadko goszczą na kartach rozważań literatury przedmiotu. Ich istota sprowadzała się do stwierdzenia nieważności bądź uchylania jakiegokolwiek aktu prawnego, wadliwego, tzn. wydanego z pogwałceniem prawa ${ }^{59}$. Przypominało to orzeczenia współczesnych sądów konstytucyjnych (uznających sprzeczność z ustawą zasadniczą niższych rangą aktów prawnych) ${ }^{60}$, ewentualnie wyroki sądów kasacyjnych (uchylających prawomocne orzeczenie sądowe ze względu na obrazę prawa materialnego lub procesowego $)^{61}$. Tę kategorię, ze względu na jej nieco odrębny praw-

dwu różnych typów konstytucji, jest w naszym przekonaniu niezasadne w świetle ich analogicznej funkcji w systemie prawnym i podobieństwa stosowanych w ich tworzeniu technik legislacyjnych. Ich istotną treścią było, niewątpliwie nietypowe z punktu widzenia ustawodawstwa współczesnego, uprawnienie sejmu, do wydawania uchwał dokonujących swoistej legislacyjnej reminiscencji, restytucji albo wyjaśnienia obowiązujących już norm prawnych.

${ }^{59}$ Określenie ,wady” prawnej rozumiemy, zgodnie z uwagami przedstawionymi powyżej szeroko, jako niezgodność tak z prawem pisanym, jak i regułami wyznaczanymi przez moralność, tradycję, kulturę prawna, czy wskazania bieżącej, opartej na powszechnej zgodzie, polityki.

${ }^{60}$ Tak np. w sprawie nielegalnych listów ,przepowiednich” na zaciąg wojska przeznaczonego na wyprawę skierowaną przeciwko Turcji, którą planował w końcowych latach panowania Władysław IV. Zgodnie z konstytucją z $1646 \mathrm{r}$. poczynione przez króla nielegalne zaciągi (dokonane bez zgody sejmu i przy wyraźnej odmowie opieczętowania wystawionych na nie listów przez kanclerzy) rozwiązano (por. VL, t. IV, s. 43-44, fol. 83-85). Co interesujące w tym kontekście, omawiana decyzja wywierała skutki ex nunc, czyli nie unieważniała poczynań królewskich z mocą wsteczną, mimo ich oczywistej bezprawności.

${ }^{61}$ Najlepszym przykładem są tu amnestie (znacznie częstsze w II poł. XVII i w początkach XVIII w.), stosowane jako środki eliminacji wyroków skazujących za przestępstwa polityczne. Takie działania nie zawsze wynikały z ewidentnego naruszenia prawa w fazie wyrokowania, mogły dotyczyć niezasadności wyroku w świetle zasad moralności, „słuszności” i politycznych zwyczajów, czyli konieczności osiągnięcia zgody i pacyfikacji konfliktów „,między bracią”, posiadających w ówczesnej kulturze prawnej w zasadzie walor zbliżony do norm prawnych (jeśli nie stanowiły wprost źródeł prawa). W uzasadnieniu konstytucji pt. Amnistya z sejmu 1609 r., czytamy: „Iakośmy się (...) na początku rozruchów domowych starali, aby to co serca obywatelów (...) strwożyło (...) spólną raczey zgodą (...) nie tumultem znoszono bydź mogło; tak y teraz, gdy nas P. Bóg po tych mięszaninach znowu z miłosierdzia swego do pierwszey iedności (...) przywiódł, chcemy w tym (...) Oycowską naszę benignitatem przeciw tey zacney Rzpltey (...) pokazać. I chociażmy od niektórych obywatelów państw naszych (...) w dostoieństwie swoim są urażeni, spólney oyczyźnie daruiemy, y onych in perpetuum zapominamy y uniwersały przeciw nim (...) wydane podnosimy". Fragment ten wskazuje jasno motywy działania królewskiego, argumenty religijne (wola Boga) i moralne (,strwożenie” obywateli działaniami króla i jego „ojcowska” łaskawość względem poddanych) przeplatają się z argumentem politycznym, osiągnięciem ,jedności” między zwaśnionymi stronami konfliktu). Trudny do zinterpretowania jest fragment o ,podnoszeniu” uniwersałów wydanych przeciw rokoszanom. Fraza ta jest kompletnie bez sensu, nie wiemy, czy mamy tu do czynienia z drukarskim chochlikiem (mogło chodzić np. o słowo ,znosimy”), czy też celowo rozmywano charakter omawianej czynności. Powoduje to, że w zasadzie niemożliwym jest ustalenie, czy dekrety uchylono, czy unieważniono z mocą wsteczną. Podobny walor miało znoszenie wyroków nakładających infamię w zamian za późniejsze zasługi (wyrok zgodny z prawem, ale niesłuszny w świetle godnej postawy 
ny charakter oraz ograniczone rozmiary niniejszego szkicu, pominiemy w dalszych rozważaniach.

Uchwalanie konstytucji egzorbitancyjnych można zakwalifikować jako odmianę wyodrębnionej we współczesnej teorii prawa, kategorii tworzenia go poprzez „odkrywanie”. Doktryna ta traktuje legislację ,,(...) nie tyle jako »tworzenie« prawa, ile jako »odkrywanie« reguł powstałych niezależnie od prawodawcy, który tylko uznaje ich moc wiążącą"62. Taki pogląd na tworzenie prawa jest charakterystyczny dla całej ówczesnej Europy, ze względu na dominację filozoficzno-prawnej doktryny prawa natury. Należy jednak podkreślić, że istnieje zasadnicza różnica między praktyką wywodzenia aktów stanowionych z prawa natury a działalnością sejmów walnych, mających na celu potwierdzanie, powtarzanie lub objaśnianie istniejących norm prawa zwyczajowego, a zwłaszcza stanowionego. „Odkrywanie” w procesie tworzenia prawa pozahistorycznych i abstrakcyjnych norm prawa natury stanowi w istocie kolejną próbę nadania konserwatywnej „otoczki” dla stanowienia nowych ustaw, będąc raczej zabiegiem filozoficznym czy też psychospołecznym, niż prawniczym $^{63}$. Oczywiście odwołują się one w dobrej wierze do abstrakcyjnych wartości aksjologicznych, zakorzenionych w określonym systemie etycznym, najczęściej o boskim pochodzeniu, jednakże liczne kontrowersje nie tylko w ustaleniu precyzyjnego i jednolitego katalogu praw naturalnych, ale przede wszystkim brak zgody co do reguł o charakterze rudymentarnym (ze względu na istnienie licznych, często sprzecznych ze sobą systemów etycznych),

szlachcica na wojnie, por. np. sprawę słynnego dowódcy lekkiej jazdy, Aleksandra Lisowskiego, któremu ,poglądając” na jego zasługi, ,zniesiono” i ,,skasowano” wyrok infamii, VL, t. III, s. 25, fol. 44. Ponadto, co niezwykle istotne w świetle niezależności sądownictwa szlacheckiego, także wyroki wydane przez Trybunał Koronny z pogwałceniem prawa mogły podlegać uchyleniu przez sejm. Sprawa ta budziła znaczne kontrowersje ze względu na olbrzymi szacunek do szlacheckiego Trybunału, na kanwie spraw Bolestraszyckiego i Firleja rozpatrywanych na sejmie 1627 r. Sprawy te nie stanowią oczywiście właściwego przedmiotu rozważań niniejszych, odwołujemy się w tym miejscu do ustaleń literatury przedmiotu, gdzie zainteresowany czytelnik odnajdzie stan faktyczny, argumenty prawne i polityczne prezentowane w dyskusji oraz bliższe omówienie podjętych decyzji, por. J. Seredyka, Sejm zawiedzionych, s. 54 i n.; U. Augustyniak, Egzorbitancje dysydentów na sejmie 1627 roku, jako przyczynek do rekonstrukcji ich programu ideowego za panowania Zygmunta III, [w:] Studia historyczno-prawne. Księga poświęcona pamięci Profesora Jana Seredyki, red. W. Kaczorowski, Opole 2008, s. 27-48. O dalszych losach omawianych dekretów i sprawie egzekucji dotyczącej ich konstytucji, por. J. Dzięgielewski, O tolerancję dla zdominowanych. Polityka wyznaniowa Rzeczypospolitej w latach panowania Władystawa IV, Warszawa 1986, s. 160 i n. Co istotne, konstytucja uchwalona ostatecznie na sejmie 1627 r. stanowiła, iż: „Trybunał (...) według prawa od wszystkiey Rzeczyposp. postanowionego sądzić ma powinien, takich spraw, któreby w prawie opisane nie były, przypuszczać przed się nie ma, ani poenas irrogare ani niemi nikogo aggravare, nad to iakie są prawem pospolitym oznaczone: a gdzieby się takowe dekreta, lubo klauzuły ich nalazły, któreby vim legis saperet abo pokój pospolity wzruszali (...) do takich żaden pociagany bydź nie ma, y owszem maią nullitati subesse", VL, t. III, s. 263, fol. 547.

62 J. Wróblewski, Zasady tworzenia prawa, Warszawa 1989, s. 28.

${ }^{63}$ Por. rozważania, ibidem, s. 29-31. 
świadczą o tym, że nie jest to działanie o wymiarze technicznym, ale ma zasadnicze znaczenie dla merytorycznego kształtowania norm prawnych i całego systemu prawnego. Chociażby w sferze prawno-ustrojowej, koncepcje prawa naturalnego stanowiły przecież w epoce nowożytnej uzasadnienie dla tak odległych modeli ukształtowania rządów i systemu prawnego w państwie, jak skrajny demokratyzm (J.J. Rousseau i B. Spinoza) i absolutna, nieograniczona monarchia (T. Hobbes) albo też rząd ograniczony (J. Locke) i omnipotentny, a w zasadzie ,pretotalitarny” (Hobbes, S. Pufendorf i Rousseau). Podobnie w dziedzinie stosunków międzynarodowych prawami naturalnymi uzasadniano zarówno prawo podboju (H. Grotius i Hobbes), jak i regułę integralności terytorialnej (P. Włodkowic, F. de Vitoria). W odniesieniu do prawa gospodarczego prawem natury thumaczono zakaz praktyk lichwiarskich (św. Tomasz z Akwinu, M. Luter), jak i usprawiedliwiano stosowanie pożyczania pieniędzy na procent (katolicka szkoła scholastyczna z uniwersytetu w Salamance; J. Kalwin). Podobnie w zakresie elementarnych wolności jednostki, prawa natury bywały uzasadnieniem dla legalności niewolnictwa (Grotius), jak i dla stanowiska tę legalność kwestionującego (Locke) ${ }^{64}$.

Oczywiście „odkrywania” norm prawa natury nie można postrzegać jedynie jako konceptu filozoficznego, była to bowiem przynajmniej w pewnym stopniu technologia legislacyjna. Szczególnie ciekawą spuściznę pozostawiają w tym zakresie teorie św. Tomasza z Akwinu, który sprecyzował nawet tryb rekonstruowania norm prawa natury przy kształtowaniu konkretnych rozwiązań przez „ziemskiego ustawodawcę”. Szczególnie, że, jak podkreśla św. Tomasz, prawo naturalne nie jest $\mathrm{w}$ stanie dać $\mathrm{w}$ pełni precyzyjnych norm postępowania, ze względu na swą abstrakcyjność i ogólność. Twórca prawa ludzkiego (lex humana), powinien korzystać z dwu metod rozumowych: pierwsza z nich, conclusio - polegać miała na wnioskowaniu dedukcyjnym, druga, determinatio - na uszczegóławianiu ogólnych zasad ${ }^{65}$.

„Odkrywanie” prawa, z którym mamy do czynienia w konstytucjach egzorbitancyjnych różni się przede wszystkim charakterem norm prawa „odkrywanego". Były nimi bowiem, nie abstrakcyjne wartości (stanowiące część systemu prawa metafizycznego i nadrzędnego), ale wydane (lub uznane) w legalnej procedurze przepisy, obowiązujące formalnie, pod przymusem władzy państwowej w stosunkach społecznych i gospodarczych oraz w świadomości oby-

${ }^{64} \mathrm{Na}$ temat różnych ujęć filozoficznego i legalnego wymiaru praw naturalnych w epoce nowożytnej, patrz J. Baszkiewicz, F. Ryszka, Historia doktryn politycznych i prawnych, Warszawa 1973, s. 208-282; S. Estreicher, Wyktady z historii ustroju państwa i prawa na zachodzie Europy, Kraków 2000, s. 62-74; J. Oniszczuk, Koncepcje prawa, Warszawa 2004, s. 78-117; J. Peretiatkiewicz, Filaozofia prawa Jana Jakóba Rousseau, Kraków 1913, passim; R. Tokarczyk, Klasycy praw natury, Lublin 2009, s. 174-268.

${ }^{65}$ Por. D. Drapiewski, Prawo naturalne w ujęciu św. Tomasza z Akwinu, „Perspectiva” Legnickie studia teologiczno-historyczne, Rok IV, 2005, nr 2, s. 21. 
wateli. Dlatego powtarzanie, restytuowanie i rewitalizowanie czy konkretyzowanie wyidealizowanych, ale mających namacalny i realny charakter dawnych regulacji ,przodków” stanowiło w mniemaniu szlachty optymalną reakcję na problemy ich wspólnoty politycznej, których przyczyną był upływ czasu, degeneracja obyczajów oraz egzorbitancyjne działania władzy państwowej z królem na czele ${ }^{66}$.

\section{Konstytucje egzorbitancyjne potwierdzające obowiązujące normy.} Praktykę potwierdzania obowiązujących regulacji prawnych nazywano w staropolskim języku prawnym ,reassumpcyją”. Słowo to, wywodzące się z łaciny, w języku prawnym Polski szlacheckiej rozumiane było jako: „zebranie w całość”, „powtórzenie w skrócie”, „wznowienie”, ,przyjęcie z powrotem”67. Był to termin prawny służący potwierdzaniu obowiązywania czy też restytuowaniu obowiązujących norm, kiedy występował jakiś problem (najczęściej związany z popełnianiem egzorbitancji), który stał na przeszkodzie ich egzekwowaniu przez organy władzy ${ }^{68}$. H. Olszewski trafnie zauważa, że w źródłach pojawiają się terminy synonimiczne względem „reassumpcji”, jak ,aprobacja”69. Do wska-

${ }^{66}$ Wynikało to z ideologicznej apologetyzacji przez naród polityczny Rzeczypospolitej przedrozbiorowej własnego systemu prawnego i głęboko zakorzenionego w mentalności polskiej szlachty przekonania o jego pełnej zdolności do realizacji wszelkich (ograniczonych zresztą) zadań państwa, co stanowiło ujęcie zasadniczo odrębne od rodzącej się myśli absolutystycznej, która doprowadziła do wykształcenia się w Europie zachodniej tendencji (trwającej zresztą do dziś) do uchwalania norm prawnych w celu rozwiązywania ad hoc bieżących problemów polityki. Istniały oczywiście na zachodzie Europy teorie, wskazujące na konieczność ograniczenia władzy prawodawczej i podkreślające konieczność zagwarantowania jej wstrzemięźliwości w zmienianiu obowiązującego prawa. Brały one jednak za punkt wyjścia przekonanie odmienne od polskiej doktryny, akcentowały bowiem pesymizm i sceptycyzm względem skuteczności jakichkolwiek usiłowań państwa, co stanowić miało naturalną konsekwencję ułomności natury ludzkiej (tak np. w teoriach Michała de Montaigne'a oraz Marcina Lutra, por. S. Filipowicz, Historia myśli polityczno-prawnej, Gdańsk 2001, s. 161-163, 167 i n.). Dopiero podążający za myślą Jana Locke'a liberalizm XIX wieku przyjął za podstawę ograniczania swobody w ustanawianiu i zmienianiu obowiązującego stanu prawnego uzasadnienie optymistyczne, podając $w$ wątpliwość nie tyle skuteczność takich ingerencji, ile ich zasadność w świetle praw naturalnych i interesów jednostki. Analizę sporu, kanwę którego stanowiło w nauce polskiej wskazywanie paranteli między doktryną polityczną szlacheckiej Rzeczypospolitej a poglądami zachodnioeuropejskiego liberalizmu, przedstawił H. Olszewski, Doktryna złotej wolności i spory o jej spuściznę, „Państwo i Prawo”, 2001, z. 2, s. 3-17.

${ }^{67}$ Stownik wyrazów staropolskich oraz łacińskich częściej używanych, [w:] J.A. Chrapowicki, Diariusz, część druga: lata 1665-1666 r., oprac. A. Rachuba i T. Wasilewski, Warszawa 1988, s. 559.

${ }^{68}$ Naturalnie także wspominane już na łamach niniejszego artykułu ratyfikowanie traktatów międzynarodowych było technicznie realizowane poprzez reasumowanie tychże, jednak w tym przypadku oznaczało oczywiście konstytutywne nadanie im mocy prawnej (stanowiąc warunek ich wejścia w życie). Można jednakże spotkać w źródłach użycie tegoż pojęcia w innym kontekście, np. wznowienia obrad jakiegoś ciała kolegialnego (np. izby poselskiej w sejmie), ew. sesji sądowej (por. w zakresie działalności Trybunału Koronnego, T. Bednaruk, Trybunał Koronny. Szlachecki sqd najwyższy w latach 1578-1794, Lublin 2008, s. 134-142.

${ }^{69}$ Por. H. Olszewski, Sejm w dawnej Rzeczypospolitej: ustrój i idee, t. 1: Sejm Rzeczypospolitej epoki oligarchii (1652-1763): prawo, praktyka, teoria, programy, Poznań 2002, s. 395. Pojęcie „re- 
zanego katalogu dodać należy jeszcze takie sformułowania, jak: „przychylenie

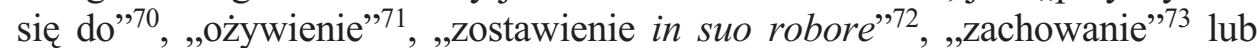
„utwierdzenie" ${ }^{\prime 4}$ konstytucji. Naturalnie nie jest to ani zamknięty, ani wyczerpujący katalog tego typu określeń.

asumpcja” było oczywiście zdecydowanie najpopularniejsze i najpoprawniejsze prawniczo, ze względu na swe łacińskie pochodzenie, por. np. VL, t. III, s. 13, fol. 18; s. 99, fol. 204; s. 152, fol. 312; s. 157 fol. 324 ; s. 170 , fol. 351 ; s. 184 , fol. 379 ; s. 277, fol. 577 ; s. 289 , fol. 603 ; s. 340 , fol. 711 ; s. 377 , fol. 796 ; s. 385 , fol. 811; s. 403, fol. 850; s. 443, fol. 933; s. 448, fol. 994. Pojęcie „aprobacja” było szczególnie popularne przy potwierdzaniu aktów o charakterze indywidualnym i konkretnym, zarówno konstytucji sejmowej, jak i przywileju czy innego aktu królewskiego, por. np. VL, t. III, s. 146, fol. 301; s. 159, fol. 328; s. 332, fol. 695. Aprobowano także skrypty ad archivum, por. np. VL, t. III, s. 294, fol. 612. Możliwe było używanie obu tych pojęć równolegle w jednej konstytucji ,w ramach powszechnej w ówczesnej technice legislacyjnej multiplikacji synonimów (np. ,[...] tę konstytucyą 1607 in toto reassumuiąc, we wszystkich punktach approbuiemy”, VL, t. III, s. 12, fol. 15, patrz też m.in. VL, t. III, s. 15, fol. 21; s. 209, fol. 432). Terminu ,przypomnienie” w konstytucjach opisywanego przez nas okresu historycznego w Zbiorze Praw nie odnaleźliśmy. Autor wymienia tu także frazę ,przywiedzenie do egzekucji”, której znaczenie dla przedmiotu naszych rozważań omawiamy bliżej w dalszej części pracy. Wspomina także o terminie „sprostowanie”, w konstytucjach uchwalonych na sejmach w zakreślonym przez nas okresie historycznym nie spotkaliśmy się z jego zastosowaniem w omawianym kontekście. Zresztą, semantyczny wymiar tego pojęcia nie odpowiada do końca właściwej funkcji reasumpcji.

${ }^{70}$ Jest to określenie w omawianym kontekście stosowane bardzo specyficznie: „(...) uchwałą Seymu tego waruiemy, aby składne (...) [y] przy nim chodzące akcydencya arendowane nie były: ale przychylaiąc się do konstytucyi anni 1616 [podkr. - T. K.], aby to składne (...) in administratione było szlachcica dobrze osiadłego (...)", VL, t. III, s. 281, fol. 585. Mamy tu z zasady do czynienia z fuzją reasumowania za pomocą specyficznej formuły (,przychylenia się”) i parafrazy regulacji. Por. także m.in. VL t. III, s. 157, fol. 324; s. 281, fol. 585.

${ }^{71}$ Tego słowa używano rzadko dla określenia przywrócenia lub przedłużenia obowiązywania konstytucji czasowych: „Także też konstytucyą o tumulciech, in toto, iaka iest sama w sobie, na ten czas ożywiamy (...)", VL, t. II, s. 366, fol. 1451.

72 „Przychylaiąc się do konstytucyi o frymarkach starych, z Antecessorami naszemi uczynionych, które są in revisione literarum przyięte y na Seymach ad annum 1596, approbowane, in suo robore wiecznemi czasy zostawuiemy [podkr. - T. K.] a żeby do wątpliwości nigdy przywiedzione nie były”, VL, t. II, s. 369, fol. 1457. Niekiedy redagowane w formie zostawienia ,, in toto”, „,w cale”, albo „w mocy” lub „przy mocy”. Przykłady zastosowania por. m.in. VL, t. II, 463, fol 1662; s. 466, fol. 1669; 468, fol. 1673; s. 470, fol. 1678; 471, fol. 1679; t. III, s. 6, fol. 3; s. 8, fol. 8; s. 158; s. 177, fol. 365; s. 207, fol. 427; s. 311, fol. 650. Możliwe było ,zostawienie”, nie tyle konstytucji, ile wynikających z niej praw lub obowiązków, por. np. „Nierządem y niedozorem w ustawach Woiewodzych urzędów, wielka się szkoda dzieie, którą powinność, iako im należąca, przy nich zostawuiemy [podkr. - T. K.] (...)", VL, t. II, s. 441, fol. 1614.

${ }^{73}$ „Także około sądów z żołnierzami, konstytucyą anni 1593 in toto zachowuiąc [przyp. T. K.] (...)”, VL, t. III, s. 374, 788, por. także np. VL, t. III, s. 328, fol. 687. Niekiedy w formie ,zostawienia in suo esse", por. VL, t. II, s. 463, fol. 1661. Tutaj również możliwe było potwierdzenie nie samego aktu konstytucji a wynikającego z niej uprawnienia: „Przywiley od Króla Stephana, przodka naszego, na młyn na przedmieściu naszym lwowskim (...) szpitalowi Lwowskiemu Ormiańskiemu (...) za zezwoleniem wszystkich Stanów approbuiemy y w używaniu tego młynka szpital (...) zachowuiemy [podkr. - T. K.] (...)", VL, t. III, s. 9, fol. 10. Patrz również m.in. VL, t. III, s. 88, fol. 179; s. 90 , fol. 183 ; s. 101, fol. 208 ; s. 120, fol. 245; s. 143, fol. 295; s. 226, fol. 470; s. 240 , fol. 500

74 „Konstytucję anni 1607 o przepisaniu ksiag Ziemskich Kiiowskich we wszystkim utwierdzamy [podkr. - T. K.] (...)", VL, t. III s. 13, fol. 18 por. też m.in. VL, t. II, s. 442, fol. 1615, 470, fol. 
Reasumpcja mogła przybierać formę krótkiej wzmianki o regulowanej materii wraz z rokiem wydania obowiązujących w danym zakresie konstytucji (jednej lub wielu), ewentualnie tożsamych z nimi statutów, a także przywilejów monarszych i innych aktów wydawanych przez króla w sprawach na styku kompetencyjnym z sejmem ${ }^{75}$. Przy reasumpcji nie było oczywiście konieczne szczegółowe dookreślanie tytułu i daty aktu, który był reasumowany, często ograniczano się jedynie do wskazania zakresu przedmiotowego konstytucji i imienia monarchy, z czasów panowania którego pochodziła dana uchwała, zdając się na kulturę prawną i orientację organów państwa i jego obywateli ${ }^{76}$. Niekiedy brak precyzji był nad wyraz klarowny, tak że umieszczano w konstytucji reasumującej tylko lapidarną formułę o potwierdzeniu obowiązujących w danym zakresie „,dawnych praw”77. Co ważne, analogiczny charakter prawny do „reasumpcji” miało także powtórzenie lub nawet sparafrazowanie obowiązującej regulacji ${ }^{78}$. Oczywiście możliwym było, iż za-

1678, s. 471 , fol. 1680 ; t. III, s. 12 , fol. 17; s. 94 , fol. 193; s. 181, fol. 373 ; s. 184, fol. 376 ; t. IV, s. 56 , fol. 111 ; s. 67 , fol. 133 .

${ }^{75}$ Bardzo klarowną prawniczo i modelową, choć naznaczoną typową tendencją do gmatwania treści, jest konstytucja dotycząca mazowieckich składów solnych, którą przytoczymy w całości: „Konstytucyą anni 1589 sub titulo składy solne Mazowieckie, iż do skutku nie przychodzi, za prośbą Posłów tegoż Woiewództwa Mazowieckiego, reassumuiemy, y żeby w egzekucyą przywiedziona była postanawiamy”, VL, t. III, s. 145, fol. 298. Zdarzało się jednakże używanie reasumpcji w nieco inny sposób, kiedy uchwałodawca wprowadzał jakiś wyjątek od obowiązujących zasad i pragnął zabezpieczyć się przed jej lekceważeniem na przyszłość, przez podmioty nie objęte zakresem wyjątku tak np. w konstytucji o incompatibilitas z 1633 r.: ,„...) konstytucya anni 1627 zabrania, aby Biskupstwa pospołu z Opactwy, albo probostwy zakonnymi trzymane nie były, dla tego bacząc (...) szczupłą intratę pewnych Biskupstw (...) dla każdego z nich wolno Nam będzie mieć wzgląd, y seorsivo aliquo ale unico tylko beneficio szczupłość tych Biskupstw roportionaliter supplere: co in sequelam inszym Biskupstwom wszystkim iść nie ma; y owszem konstytucye de incompatibilibus, na takowych reassumuiemy, którzy ważyli się do biskupstw w tey konstytucyi nie specyfikowanych, beneficium iakie kościelne upraszać (...)”, VL, t. III, s. 379, fol. 799-800.

${ }^{76}$ Była to praktyka nagminna, wynikająca prawdopodobnie raczej z niechlujstwa legislacyjnego niż ze świadomej woli ustawodawcy. Por. np. „(...) reassumuiąc dawne statuta y konstytucye [podkr. - T. K.] o składach w miastach koronnych (...)", VL, t. III, s. 289, fol. 604.

${ }^{77}$ „Ażeby się w tym żądnościom Stanów wszystkich dogodziło, y nie zostawał żaden skrupuł u nikogo, de usurpando absoluto dominio contra leges regni od czego dalecy y sercem y myślą iesteśmy: Konstytucie o mieszkaniu Senatorów, Królów Henryka y Stefana, przodków naszych in toto reassumuiąc [podkr. - T. K.] (...) na tym seymie z Senatu osób szesnaście (...) deputuiemy (...)", VL, t. II, s. 433-434, fol. 1596-1597.

${ }^{78}$ Inaczej I. Lewandowska-Malec, op. cit., s. 564. Należy podkreślić, iż stosowano taką praktykę nad wyraz rzadko, ale kategoryczne stwierdzenie, że nie powtarzano treści konstytucji zawsze posługując się ogólną formułą rerasumpcyjną jest zbyt daleko idące. Działo się tak zapewne przede wszystkim ze względu na wylewność barokowego języka, krótka konstytucja o reasumowaniu jakiejś nierespektowanej normy musiała się wydawać szlachcie nieatrakcyjna, ze względu na swoją lapidarność, wydłużano ją więc powtarzaniem czy parafrazowaniem treści pierwotnej normy. Przykładem może być potwierdzenie wspomnianej już przez nas konstytucji o dekretach trybunalskich z 1627 r., dokonane w 1638 r. Treść pierwszej z nich cytujemy w przypisie 60. Druga redakcja brzmi następująco: „Acz iest to prawem pospolitym, osobliwie konstytucyą anni 1627 dostatecznie warowano, aby Trybunał spraw takowych, które w prawie opisane nie są, przed się nie przypuszczał, y ni- 
mieszczone w konstytucji odwołanie do innego aktu prawnego pełniło rolę normy odsyłającej ${ }^{79}$.

Potwierdzenie obowiązywania konstytucji stanowiło w zasadzie formę pośrednią między tylko powtarzaniem istniejących regulacji a uchwalaniem nowych, między stwierdzaniem obowiązywania prawa a nadawaniem mocy nowym przepisom. Istotą tej praktyki było restytuowanie i „rewitalizowanie” przepisów już uprzednio legalnie wprowadzonych do systemu prawnego. Reasumpcji przydawano swoisty surogat sprawczej mocy legislacyjnej, uważano, że stanowi ona „przywiedzenie konstytucji do egzekucji”, tzn. uznawano, że ma wywołać określone efekty w zakresie praktyki administracyjnej i sądowej $^{80}$. Z technicznego punktu widzenia instytucja ta przypominała współcześnie znane akty o charakterze deklaratoryjnym, potwierdzała bowiem obowiązywanie przepisów już istniejących, autorytatywnie, wolą uprawnionego organu $^{81}$. Celem takiego działania miało być zatem doprowadzenie do egzekucji obowiązujących przypisów, czyli zapobieganie ich łamaniu i lekceważeniu w przyszłości.

Konstytucje o charakterze reasumującym, w przeciwieństwie do ustaw wprowadzających zupełnie nowe regulacje, nie uchylały obowiązujących $\mathrm{w}$ danym zakresie przepisów zgodnie z regułą kolizyjną lex posterior derogat legi priori. Dotyczyło to nie tylko redakcji najnowszej, ale także wszystkich wcześniejszych, co oczywiste, o zgodnej treści ${ }^{82}$. Świadczy o tym częsta prak-

mi nikogo nie aggrawował; iż iednak w tym prawu pospolitemu dosyć się nie dzieie, waruiemy to teraźnieyszą konstytucyą że się Trybunał podług prawa pomienionego wcale zachowywać będzie powinien. A ieśliby przeciwko pomienioney konstytucyi takowe dekreta na potym stanęły, nullitatis vitio subjacere maią, y exekucyi podlegać żadney nie będą", VL, t. III, s. 444, fol. 936. Przytoczona norma zawiera wszystkie elementy pierwotnej, pierwotna redakcja jest bardziej wylewna, ale nie zawiera innych, szerszych czy bardziej szczegółowych uregulowań.

${ }^{79}$ Por. np.: ,,...) o co forum z appellacyą mieszczanie, y postępek taki mieć maią iako konstytucyą anni [15]81 opisano", VL, t. II s. 441, fol. 1614. Wskazuje na to zjawisko I. Lewandowska-Malec, op. cit. s. 561-567. Autorka zdaje się uznawać takie stosowanie reasumpcji za modelowe, nie wykluczając jednakże używania tej techniki w omawianym przez nas rozumieniu, por. ibidem, s. 572.

${ }^{80}$ Fraza, podług której reasumowanie konstytucji oznaczało „przywiedzenie ich do egzekucji” bądź „efektu”, pojawia się w Voluminach legum dość często, patrz m.in.: VL, t. II, s. 433-434, fol. 1596-1597, s. 441, fol. 1613; s. 447, fol 1626; VL, t. III, s. 297, fol. 619

${ }^{81} \mathrm{O}$ współczesnych administracyjnych aktach deklaratoryjnych, patrz E. Ochendowski, Prawo administracyjne, Torun 2005, s. 180-181.

${ }^{82}$ Oczywiście problematyczna była tu sytuacja braku zgodności w treści norm, których obowiązywanie potwierdzano przez niedokładne parafrazowanie obowiązującej redakcji szczególnie dobitnym przykładem są regulacje dotyczące tzw. „napomnienia” monarchy, czyli procedury, która musiała poprzedzać formalny akt wypowiedzenia posłuszeństwa królowi ze względu na popełnione przez niego egzorbitancje. Norma uchwalona w roku 1607 (por. VL, t. II, s. 452, fol. 1636-1637) różni się diametralnie od regulacji w analogicznym przedmiocie uchwalonej w roku 1609 (VL, t. II, s. 462-463, fol. 1660-1661). Zwrócił na ten fakt uwagę już J. Szujski, choć nie zanalizował bliżej istoty ani charakteru dystynkcji i nie wyciągnął z nich żadnych istotnych wniosków, por. J. Szujski, Artykuł o wypowiedzeniu postuszeństwa. Przyczynek do dziejów konstytycyi polskiej, [w:] Dzieła Józefa Szujskiego, wydanie zbiorowe, Kraków 1888 r., serya 2, t. VII, s. 338-340. Co istotne dla 
tyka enumeratywnego wymieniania przy reasumpcji wszystkich konstytucji $\mathrm{w}$ danej materii, a nie tylko jednej, ostatniej ${ }^{83}$. W takim przypadku wszystkie te konstytucje wspólnie stanowiły podstawę prawną dla działań władzy wykonawczej. Częstokroć, zwłaszcza w sytuacji, gdy dana ustawa była przegłosowywana po raz kolejny w niewielkim odstępie czasu, zdarzało się powołanie na ostatnią, tj. najnowszą redakcję ${ }^{84}$.

Omawiana konstrukcja zdaje się być z naszej współczesnej perspektywy sztuczna i irracjonalna, jeśli bowiem pierwotne uchwalenie konstytucji nie przyniosło oczekiwanych rezultatów, to trudno było oczekiwać, aby jej ponowne uchwalenie lub potwierdzenie jej mocy obowiązującej stało się skutecznym instrumentem oddziaływania, tak na organy państwa, jak i obywate$1 i^{85}$. Jednakże wiara w moc sprawczą konstytucji sejmowej, uchwalonej za

naszych rozważań, w dalszej praktyce powoływano się na obie regulacje, częściej jednak na normę wcześniejszą, czyli tę z roku 1607, co stanowi swoiste odwrócenie zasady lex posterior (tak np. w akcie praw kardynalnych z 1768 r., gdzie w zakresie samej procedury odwołano się wyłącznie do redakcji z 1607 r., z uchwały 1609 r. potwierdzono jedynie odpowiedzialność delatora w przypadku bezzasadności oskarżenia, por. VL, t. VII, s. 281, fol. 600). Trudno się więc dziwić, iż to redakcję z 1607 r. uznał za podstawę prawną napomnienia W. Uruszczak, Zasady..., s. 151 (w podręczniku prof. Uruszczaka niedopatrzenie to zostało skorygowane i jako podstawę ,napomnienia” autor wskazał zarówno redakcję z 1607, jak i z 1609 r., choć bez przytoczenia występujących między nimi różnic, por. W. Uruszczak, Historia państwa, s. 213). Warto dodać, iż regulacje dotyczące „,napomnienia” stanowią z punktu widzenia formalnego „objaśnienia” artykułu o wypowiedzeniu posłuszeństwa, w rzeczywistości jednak są to raczej regulacje nowatorskie. Mamy tu zatem do czynienia z ciekawym przypadkiem nadużycia omawianej techniki legislacyjnej; zwraca na to uwagę nawet anonimowy XVII publicysta: Śmiertelne rany Rzeczypospolitej naszej, [w:] Pisma polityczne z czasów rokoszu Zebrzydowskiego, wyd. J. Czubek, Kraków 1918, t. III, s. 372-374.

${ }^{83}$ Patrz np.: , ,...) artykuły konstytucye woienne w konstytucyach annorum 1591, 1593, 1601, 1609, 1620 [podkr. - T. K.] uchwalone y peny w nich opisane in toto reassumuiemy (...)", VL, t. III, s. 239, fol. 496.

${ }^{84} \mathrm{~Np} .:$, ,...) reassumuiąc prawa wszystkie dawne o soli Bydgoskiey, a osobliwie konstytucją roku 1576 [podkr. - T. K.] (...)”, VL, t. III, s. 264, fol. 551.

${ }^{85}$ Warto w tym miejscu podkreślić, że stosowanie instytucji reasumpcji w działaniach mających na celu naprawę egzorbitancji piętnowali często już współcześni. Wskazywali oni na bezużyteczność takiej działalności w kontekście egzekwowania konstytucji i innych praw gwałconych przez administrację i wymiar sprawiedliwości. Doskonałym odzwierciedleniem tego sposobu myślenia jest passus pochodzący z mowy A. Moskarzewskiego na sejmiku proszowickim, wygłoszonej w czasie jego obrad w roku 1634. W tekście tym czytamy: „sposób zasię uprzątnienia egzorbitancyj, których jest bez liczby, nie ten być rozumiem, aby praw abo nowych przyczyniać, abo żeby dawne reasumować (...) ale raczej nazradniejszy sposób do zatrzymania wszystkiego w swej porze rozumiem (...) przetoż ja z miejsca mego egzorbitancyj roztrząsać nie będę (...) żebyście wm tak wiele tu artykułów, a potym i konstytucyi na sejmie pisać mieli. Telko tego popiram, żebyście wm prawa dawne, które dosyć dobre i ostre są (...) do egzekucyjnej przywodzili, albo wżdy kiedy jaki sposób na sejmie communicatis consiliis wynaleźli, którym by prawa osłabione przez egzekucyją skuteczną w rezę wprawione były", Akta sejmikowe województwa krakowskiego, wyd. A. Przyboś, t. II, Kraków 1953-55, s. 185. Moskarzewski uznaje reasumowanie ustaw za niepotrzebne i bezproduktywne mnożenie konstytucji, nie tylko niestanowiące instrumentu poprawy skuteczności egzekucji prawa, ale wręcz przeciwnie, przeszkadzające w niej, albowiem prowadzące do marnowania cennego czasu obrad sejmowych na ucieranie tekstu konstytucji. Egzorbitancje nie powinny były zatem, według niego, w ogóle 
zgodą trzech sejmujących stanów była w Polsce przedrozbiorowej ogromna i tym należy tłumaczyć istnienie tej, nieco naiwnej, koncepcji i jej zadziwiającą popularność. Postulaty „,reasumpcyjne” były formułowane permanentnie, przy czym nasilały się w chwilach kryzysów politycznych, wywołanych oburzeniem szlacheckiej opinii publicznej na działania dworu, tudzież innych podmiotów, w sferze publicznej.

Reasumowanie konstytucji stanowiło niewątpliwie ciekawą instytucję prawną. Z biegiem czasu uległo jednakże znaczącej degeneracji, jak cały system ustawodawstwa Polski szlacheckiej. Było nadużywane, od połowy wieku XVII stanowiąc w zasadzie podstawę działalności legislacyjnej, co samo w sobie stanowi fakt aberracyjny, będący ewidentną anomalią ustrojową ${ }^{86}$. Lektura konstytucji sejmowych tego typu wskazuje zreszta, iż omawiany instrument był używany raczej bezmyślnie i przez to nie wypełniał właściwie swej funkcji.

\section{Konstytucje egzorbitancyjne objaśniające obowiązujące normy.} Reasumowanie konstytucji sejmowej, wbrew naszym współczesnym intuicjom i wyobrażeniom, stanowiło w zasadzie modelową aktywność legislacyjną sejmu w zakresie naprawy egzorbitancji, będących wyrazem lekceważenia i łamania idealnego prawa ,przodków”. Szlachta dostrzegała wszelako, iż był to środek, który czasami mógł się okazać niewystarczającym, zdarzało się przecież, iż niektóre normy „dawnego prawa” były nieprecyzyjne tudzież archaiczne i potrzebowały pewnej modyfikacji, by mogły być z powodzeniem stosowane $\mathrm{w}$ praktyce ${ }^{87}$. Legislacja ówczesna nie stała na poziomie szczególnie wysokim, co stwarzało pole do nadużyć ze strony egzekutywy, zauważanych przez opinię publiczną. Biorąc pod uwagę szczególną idiosynkrazję szlachty wobec zwiększania uprawnień króla i jego urzędników, poprzez pozostawianie im luzów decyzyjnych, jak również jej obsesyjną obawę przed arbitralnością władzy, jasna staje się tendencja do maksymalnego uszczegóławiania i konkretyzacji zapisów ustawowych, doprecyzowania niejasnych i nazbyt

uzyskiwać formy aktów legislacyjnych, a należało je załatwiać działaniami w wymiarze kontrolnym i politycznym (konkretnych rozwiązań autor nie podaje). Praktyka ustawodawstwa (z dominująca rolą reasumpcji), jak również zachowane propozycje dotyczące egzorbitancji dowodzą jednakże, iż był to głos mniejszościowy, choć wart zauważenia.

${ }^{86} \mathrm{Na}$ nadużywanie i nieskuteczność reasumpcji zwraca uwagę W. Sobociński, Pakta konwenta, Kraków 1939, s. 61.

${ }^{87}$ Symptomatyczna jest tu opinia związanego z dworem J. Januszewskiego: „mówią niektórzy, że dobre prawa mamy, poprawy nie potrzebują. To prawda, że prawa są dobre, in genere mówiąc, i żaden ich zganić nie może: źleby bowiem było, gdzieby prawa dobre być nie miały. Ale przystępując ad speciem, co rzeczemy do praw zastarzałych, niedostatecznych, wątpliwych, abrogowanych, sobie przeciwnych, z jednego sejmu na drugi odesłanych, które temporaneae, doroczne albo próżne były. (...) Zaż te nie potrzebuja poprawy?” (...),,staną́by mogły i staną́ za czasem musza, a przedsię bez szkody i naruszenia praw dawnych", Wywód J. Januszowskiego i obmowa z strony statutów koronnych od siebie dla correctury praw sporzadzonych spisanych $i$ wydanych w Krakowie 1602, [w:] Dwie broszury prawne z r. 1602 i 1608, wyd. B. Ulanowski, Kraków 1920, s. 15. 
ogólnikowo sformułowanych przepisów, szczególnie tych faktycznie naruszanych przez władzę w praktyce rządzenia. Szlachta dopuszczała więc możliwość wprowadzania w treści obowiązujących konstytucji drobnych zmian, ale tylko takich, które nie naruszałyby sensu ani ducha regulacji czyli mających charakter raczej kosmetyczny niż zasadniczy. Tego typu akty modyfikujące normy obowiązujące w celu ich skutecznej realizacji stanowiły ciekawe zjawisko w ówczesnej praktyce legislacyjnej. Ze względu na swój charakter zawierały one z zasady rozstrzygnięcia i wytyczne o charakterze technicznym, mniej przesyconym aksjologia.

Podstawową techniką legislacyjną stosowaną w tego typu praktykach było umieszczanie w konstytucji słowa „objaśnienie”88, rzadziej „melioracja”89. Jeszcze częściej uciekano się do formuły „deklarowania” i „postanawiania” odnośnie do obowiązującej normy, czyli wykorzystano w omawianym kontekście frazy charakterystyczne dla stanowienia nowych praw ${ }^{90}$. Relatywnie często zdarzało się używanie w omawianym kontekście w konstytucjach objaśniających nieprecyzyjnego, bo używanego w licznych kontekstach i znaczeniach czasownika „warować" ${ }^{1}$. Naturalnie, ze względu na podkreślany już wielokrotnie brak precyzji terminologicznej możliwe było zastosowanie innych wyrażeń $^{92}$. Alternatywną techniką objaśnienia było, spotykane na kartach Volu-

${ }^{88}$, ,...) przychylaiąc się do konstytucyi anni 1581, et anni 1588, o feudach Ruskich y Podolskich waruiemy to authoritate Conventus praesentis (...) tak to obiaśniając [podkr. - T. K.] (...)", VL, t. III, s. 443, fol. 1617. Por. także m.in. VL, t. II, s. 433, fol. 1596; s. 441, fol. 613; s. 443, fol. 616 oraz fol. 1618; s. 468 fol. 1672; s. 468, fol. 1673; t. III, s. 146, fol. 301; s. 185, fol. 382.

${ }^{89}$ Częstsze w publicystyce, por. np. opinię księcia K. Radziwiłła z konwokacji wileńskiej 1632 r.: ,wszystko, cokolwiek w prawach i wolnościach naszych egzorbitowano, nie tylko w dawną rezę swoją, ale też i w znaczną meliorację sufficienter wprawione [było]", cyt. [za:] W. Kaczorowski, Sejmy konwokacyjny i elekcyjny w okresie bezkrólewia 1632 r., Opole 1986, s. 44.

90 „(...) Przychylaiąc się do konstytucyi anni 1550 et 1588, którymi warowano iest, aby na opactwa y probostwa zakonne (...) ludzie niegodni nie wstępowali (...) postanawiamy, aby [podkr. - T. K.] (...)”, VL, t. II, s. 437, fol. 1605. „(...) mocą Seymu tego artykuły (...) w konstytucyach annorum $1590,1593,1601,1609,1620$, a osobliwie 1626, y 1628 de disciplina militari (...) in toto reassumuiąc, insuper deklaruiemy (...) [podkr. - T. K.] (...)", VL, t. III, s. 374, fol. 789-790. Por. także m.in. VL, t. II, s. 436, fol. 1602, s. 438, fol. 1607; s. 442-443, fol. 1616-1617, s. 468, fol. 1673; t. III, s. 6 , fol. 3 , s. 10 , fol. 12 ; s. 100 , fol. 207 ; s. 138 , fol. 282 ; s. 223 , fol. 463 ; s. 252 , fol. 524 ; s. 289 , fol. 604 ; s. 294 , fol. 613 ; s. 311 , fol. 650 , s. 333 , fol. 698 ; s. 378 , fol. 797 ; s. 385 , fol. 812 t. IV, s. 60 , fol. 119. Szczególnie ciekawe są formy hybrydalne, np. w konstytucji 1616 r. dotyczącej bezpieczeństwa sądów województwa krakowskiego, w tytule mowa jest o „deklaracji” konstytucji, a w treści normy zawarto sformułowanie „objaśnienie”, por. VL, t. III, s. 137, fol. 281. Jeszcze większy problem sprawia interpretatorowi konstytucja, w której uchwałodawca stanowił: „(...) wątpliwości obiaśniaiąc (...) postanawiamy”, VL, t. III, s. 134, fol. 276, podobnie także np. VL, t. III, s. 383, fol. 807.

${ }^{91} \mathrm{~Np}$. w objaśnieniu konstytucji o obowiązkach i uprawnieniach żupnika ruskiego, odnośnie składu solnego w Bydgoszczy z 1607 r.: ,,iednak [obywatele koronni - T. K.] uskarżaią się, że się tey konstytucyi dosyć nie dzieie (...) przeto potwierdzaiąc tę konstytucyą, waruiemy [podkr. T. K.], aby (...)", VL, t. II, s. 442, fol. 1614-1615. Patrz także m.in. VL, t. II, s. 443, fol. 1618; t. III, s. 219 , fol. 455 ; s. 375 , fol. 791 ; t. IV, s. 59 , fol. 117.

${ }^{92}$ Por. np.: „Dla gotowości ludzkiey ku obronie konstytucyą ani 1562 y drugą anni 1563 o okazowaniu do exekucyi przywiedziemy, y to mieć chcemy, aby (...)”, VL, t. II, s. 438, fol. 1606. „Kon- 
minów Legum, potwierdzenie obowiązywania konstytucji sejmowej za pomocą parafrazy określonej normy, z przydanym fragmentem nieobecnym $\mathrm{w}$ poprzedniej redakcji ${ }^{93}$. Wskazane sformułowania umieszczano z zasady po reasumowaniu obowiązującego $\mathrm{w}$ danym zakresie prawa oraz wyraźnym i dobitnym podkreśleniu, że regulacje dotychczas obowiązujące są dobre i wystarczające („,dobrze opisane”, „dość ostre” „żadnej nie popadające wątpliwości” itp.), co wyraźnie wskazuje, że nie mamy tu do czynienia z kreowaniem nowego stanu prawnego ${ }^{94}$. Oczywiście, co podkreślamy po raz kolejny, brak precyzji terminologicznej, silny wpływ polityki na prawo, słabość polskiego języka prawnego i prawniczego oraz nieszczególna dbałość o kwestie formalnoprawne także tutaj nakazują zachować ostrożność i kwalifikować do tej kategorii nie tylko na podstawie analizy semantycznej zastosowanych sformułowań, ale całokształtu treści regulacji.

Objaśnienie było zatem, podobnie jak reasumpcja, działaniem w zakresie sejmowego naprawienia egzorbitancji, miało na celu umożliwienie poprawnego egzekwowania rudymentów norm już obowiązujących ${ }^{95}$. Rozważając

stytucyą (...) warowana iest powaga dekretów Trybunalskich; tedy do tey się przychylaiąc, ustawuiemy [podkr. - T. K.], aby (...)”, VL, t. II, s. 438, fol. 1607-1608. „Konstytucyą anni 1601 o rozgraniczeniu Woiewództw Ruskiego, Podolskiego, Bełskiego, y Wołyńskiego, in toto tak ią iako w sobie iest rassumuiąc, tym dokładem, że (...)", VL, t. II, s. 467, fol. 1670.

${ }^{93}$ Tak np. w regulacji o pieczęci pokojowej, przepis z artykułów henrykowskich ujęto w słowach: „Obiecuiemy też słowem naszym Królewskim: iż My, y Potomkowie nasi, sygnetu żadnego używać nie mamy, ani pieczęci osobney w sprawach Rzeczypospolitej należących, tam intra quam extra Regnum, jeno Koronnych pieczęci, które przy Kanclerzach y Podkanclerzach są, tak Polskich, jako y Litewskich", VL, t. II, s. 161, fol. 920. Została ona potwierdzona i objaśniona w konstytucji z roku 1607: „Pieczęci pokoiowey, ani sygnetu do spraw Rzpltey, iako iest o tym, warunek Przodków naszych nie mamy zażywać. A ieśliby co in contrarium pod tą pieczęcią wyszlo, tak teraz iako y na potym, to nie ma mieć żadney wagi [podkr. - T. K.]”, VL, t. II, s. 437, fol. 1605. Dodano tu oczywista, ale expressis verbis nie wyartykułowaną w pierwotnej normie, sankcję nieważności.

${ }^{94}$ Najlepszym przykładem tego typu praktyki jest treść konstytucji o wolnej elekcji z sejmu 1607 r.: „Wolne obieranie Pana w tej Rzpltey, aczkolwiek iest tak dobrze prawem pospolitym ugruntowane, że iuż nad to pewnieyszego y iaśnieyszego nic między innemi wolnościami narodu polskiego bydź nie może, y nigdy ani przez przodki nasze, ani przez Nas w wątpliwość żadną przywiedzione nie było, y owszem, za szczęśliwego panowania naszego, osobną konstytucyą Warszawską roku P. 1593, znowu statecznie y gruntownie obwarowana iest. Iednak iż ex zelo tey wolności przednieyszey urósł był iakiś metus w tey mierze w ludziach, przeto My , chcąc hoc metu liberare poddanych naszych, y suspicye u nich wszelakie znieść, a okazać w iakim poszanowaniu prawa y swobody ich, Nam są, y zawżdy były, y będą: reassumuiemy prawa wszystkie o tym, przez przodki nasze Króle Polskie (...), y przez Nas uczynione, y one utwierdzaiąc y umacniaiąc, znowu to y teraz obiaśniamy y waruiemy (...)”, VL, t. II, s. 443, fol. 1596. Dostrzegamy tu szczególnie uroczystą formułę „objaśnienia", poza długim i szczegółowym podkreśleniem pewności i klarowności obowiązującego stanu prawnego, znajdujemy aż trzy synonimiczne wyrażenia oznaczające potwierdzenie go (,,reasumujemy”, „utwierdzamy” i „umacniamy”) oraz dwa kolejne oznaczające objaśnienie (,objaśniamy” i ,warujemy”).

${ }^{95}$ Ten egzorbitancyjny charakter szczególnie dobitnie widać $\mathrm{w}$ jednej z konstytucji sejmu 1611 r.: „Nierządem y niedozorem w ustawach Woiewodzych urzędów, wielka się szkoda dzieie, którą powinność, iako im należacą, przy nich zostawuiemy, y aby do skutku przywiedziona bydź 
abstrakcyjnie prawny charakter tego typu norm, należy zanalizować trzy nasuwające się teorie, biorące za punkt wyjścia rozwiązania znane nam ze współczesnych realiów kreowania przepisów prawnych:

1) normy konkretyzujące abstrakcyjne zasady prawne;

2) normy uzupełniające i wykonawcze (o charakterze zbliżonym do znanych współcześnie rozporządzeń wykonawczych);

3) normy dokonujące autentycznej interpretacji obowiązującego prawa.

Według pierwszej ze wskazanych teorii, „objaśnianie” praw należy rozpatrywać w analogii do współczesnego, teoretycznoprawnego rozróżniania zasad prawnych i zwykłych reguł prawnych. Te dwie kategorie norm prawnych różnią się tym, iż zasady „są bardziej pojemne, czy niedookreślone w tym sensie, że wielość różnych reguł da się przedstawić jako egzemplifikacje czy konkretyzacje jednej zasady"96. Nauka podkreśla w tym kontekście także ich aksjologiczne i teleologiczne nakierowanie, a co za tym idzie niekonkluzywność, mówiąc ściślej: niemożność wyciagnięcia tylko na ich podstawie konsekwencji prawnych przez organ stosujący prawo, na podstawie dokonania subsumpcji do konkretnego stanu faktycznego ${ }^{97}$. Mimo formalnego „wyprowadzenia przed nawias" norm klasyfikowanych jako zasady, ich moc prawna nie jest silniejsza, nie stoją one przynajmniej z czysto formalnego punktu widzenia, wyżej niż zwykłe reguły prawne. Co istotne z punktu widzenia właściwego przedmiotu niniejszych rozważań, niekompletność, nieprecyzyjność i brak technicznych szczegółów ważnych z punktu widzenia organów stosujących prawo, jest klarownie wyłaniającym się rysem konstrukcyjnym, fundamentalnych dla systemu prawno-ustrojowego przedrozbiorowej Rzeczypospolitej, norm. Widać to bardzo wyraziście przy analizie regulacji tzw. artykułów henrykowskich, cieszących się szczególną atencją w społeczeństwie szlacheckim, ale nieposiadających formalnie wyróżniającej mocy prawnej ${ }^{98}$. Najważniejsze normy artykułów mają charakter głęboko przesycony aksjologią i niekonkluzywny, by wspomnieć tylko uregulowania dotyczące: wolnej elekcji i niedzie-

mogła, konstytucye o tym uczynione obiaśniamy”, VL, t. II, s. 441, fol. 1614. Treść cytowanej uchwały wskazuje, że konstytucja reasumuje (,zachowuje”) obowiązujące normy w zakresie wydawania ustaw przez wojewodów, podkreślając przy tym, że istnieje problem związany z tymiż aktami (zachodzi „,nierząd” i ,niedozór”), powodujący negatywne skutki (,,wielką szkodę”) i to właśnie stanowi ratio legis ingerencji sejmu w postaci uchwalenia konstytucji objaśniającej. W zakresie objaśnienia także stosowano w tekstach konstytucji frazę, że miało ono oznaczać ,„przywiedzenie do egzekucji” określonej normy prawnej, por. np. VL, t. III, s. 383, fol. 807; t. IV, s. 55, fol. 108; por. także przypis 79 .

${ }^{96}$ M. Zirk-Sadowski, Wprowadzenie do filozofii prawa, Kraków 2000, s. 201.

${ }^{97}$ Szerzej o współczesnych kontrowersjach na temat konkluzywności zwykłych reguł i niekonkluzywności zasad prawnych, patrz M. Araszkiewicz, Konkluzywność reguł prawnych, [w:] Z punktu widzenia teorii prawa, red. M. Araszkiewicz, Zeszyty Prawnicze Uniwersytetu Jagiellońskiego, z. 16 , s. 43-62.

${ }^{98}$ Por. W. Sobociński, O ustawie konstytucyjnej Państwa Polskiego z roku 1573 r., „Czasopismo Prawno-Historyczne", t. I, 1948, s. 78 i n. 
dziczeniu tronu ${ }^{99}$, tolerancji religijnej ${ }^{100}$, instytucji senatorów rezydentów ${ }^{101}$, czy wypowiedzenia posłuszeństwa ${ }^{102}$. Należy wszelako podkreślić, iż sformułowanie zasad prawnych w sposób niedookreślony i przesycony aksjologia, to celowy zabieg mający ułatwić stosowanie reguł zwykłych. Zasady mogą stanowić niezwykle pomocne wskazówki interpretacyjne, a także przypominać $\mathrm{o}$ istnieniu rudymentarnych wartości nadrzędnych, determinujących w istotnym stopniu kształt systemu prawnego, w przypadkach trudnych do interpretacji dla organu stosującego prawo. Wynika to z faktu, iż zasady prawne są normami optymalizacyjnymi, tzn. „nakazującymi realizację pewnego stanu rzeczy w maksymalnym stopniu $\mathrm{z}$ uwagi na faktyczne i prawne możliwości" ${ }^{103}$. Zwykłe reguły, czyli przepisy prawa niemające waloru zasad, stanowią dziś podstawę systemu prawnego, to właśnie w celu prawidłowego egzekwowania tychże norm kształtuje się zasady. Przepisy objaśniające w Polsce przedrozbiorowej natomiast tworzono ad hoc, okazjonalnie, incydentalnie i interwencyjnie.

Drugą teorią, którą należy rozważyć, jest ujęcie objaśniających konstytucji egzorbitancyjnych jako znanych nam współcześnie, opartych na delegacji ustawowej, rozporządzeń wykonawczych. Celem takich aktów podustawowych jest odciążenie legislatora od rozstrzygania kwestii nieistotnych dla warstwy aksjologicznej aktu oraz dla znaczenia i roli jego rozwiązań, a jednak koniecznych do uregulowania. Współcześni teoretycy prawa konstytucyjnego i administracyjnego podkreślają, że tego typu akty można wydać tylko na mocy wyraźnej delegacji zawartej w ustawie i tylko w celu jej wykonania ${ }^{104}$. Niewątpliwie, „objaśnienie" wpisuje się w tendencję do uzupełniania norm prawnych technicznymi szczegółami, przydatnymi dla organów wykonawczych. Jednakże wydawanie współczesnych rozporządzeń jest praktyką stałą i świadomie zaplanowaną, podczas gdy, co już podkreślaliśsmy, do „objaśnienia” uciekano się interwencyjnie, w odpowiedzi na zaistniałe egzorbitancje.

Trzecią analogią ze współczesnym systemem prawnym, która pozwoliłaby lepiej zrozumieć istotę objaśniających konstytucji egzorbitancyjnych, jest

${ }^{99}$ Brakuje tu wyraźnie regulacji dotyczących oceny i konsekwencji ewentualnych nadużyć w tej kwestii, a także obowiązków organów w dziedzinie przeciwdziałania im.

${ }^{100}$ Ani punkt w artykułach henrykowskich, ani cały akt konfederacji religijnej nie zawierały ani wyznań objętych ochroną, ani wykazu przewinień, ani sankcji za ich popełnianie, ani procedur postępowania przez organy państwa w sprawach tego typu.

${ }^{101} \mathrm{Nie}$ ma tu żadnych regulacji dotyczących sankcji za niemianowanie rezydentów ani za uchylanie się przez nich od wypełniania obowiązków, a także formy i charakteru udzielanych porad, konsekwencji nie uwzględniania ich przez monarchę, czy też nielegalności samych rad.

${ }^{102}$ Dojmująco brakuje wymienienia podstaw odpowiedzialności królewskiej, procedury wypowiedzenia posłuszeństwa, formy, w jakiej miałoby się ono odbyć.

${ }^{103}$ M. Araszkiewicz, op. cit., s. 44.

${ }^{104}$ Por. E. Ochendowski, op. cit., s. 92 i n. 
przyrównanie ich do dokonywania autentycznej wykładni ustaw ${ }^{105}$. Istotą tego typu praktyki jest dokonywanie wykładni norm ,(...) w autoryzowanym i mającym formalnie moc wiążącą akcie”, w którym ,prawodawca wypowiada się co do znaczenia ustanowionych przez siebie norm"106. Stanisław Estreicher wskazuje, że tego typu kompetencję sejm polski posiadał i sporadycznie z niej korzystał już w XVI w. ${ }^{107}$ Dzisiejsza teoria prawa podchodzi z głęboką dozą sceptycyzmu do praktyk dokonywania oficjalnej, autentycznej wykładni, co stanowi konsekwencję restrykcyjnego przestrzegania fundamentalnej zasady, dla większości cywilizowanych państw prawa, mianowicie trójpodziału władzy ${ }^{108}$. Jednakże w Rzeczypospolitej Obojga Narodów uprawnienie sejmu do interpretowania ustaw mogło być, paradoksalnie, traktowane jako jedna z podstawowych gwarancji praworządności. Z jednej strony dawało ono możliwość ściślejszego związania administracji państwowej, a z drugiej stanowiło dogodny sposób na wyjaśnienie wątpliwości nasuwających się w procesie w praktycznej realizacji przepisu. Oczywiście punktem wyjścia znów był tu aksjomat idealności starego obowiązującego prawa, który świetnie koresponduje ze starorzymską zasadą wykładni: clara non sunt interpretanda - przepis klarowny nie wymaga interpretacji ${ }^{109}$. Zasada ta znalazła swoje normatywne odzwierciedlenie w systemie prawnym Polski przedrozbiorowej, w aktach paktów konwentów po 1632 r., przy deklaracji o naprawie egzorbitancji, wpisywano jednoznaczną deklarację, zawierającą zobowiązanie króla do stosowania prawa bez uciekania się nie tylko do kreatywnej, ale jakiejkolwiek wykładni ${ }^{110}$.

${ }^{105}$ Tak np. I. Lewandowska-Malec, op. cit., s. 560.

${ }^{106}$ L. Morawski, Zasady wyktadni prawa, Torun 2006, s. 34.

${ }^{107}$ Por. S. Estreicher, op. cit., s. 356.

${ }^{108}$ Por. L. Morawski, op. cit., s. 34-35.

${ }^{109}$ Szerzej o tej zasadzie patrz L. Morawski, op. cit., s. 49-54. Ciekawy projekt legislacyjny w omawianym zakresie przygotowano w egzorbitancjach elekcji $1587 \mathrm{r} .:$ „,...) na tym fundamencie każda R. P. cale stoi, gdy praw zupełne zachowanie i powinna exekucya bywa, co za zdrowem i wedle rozumienia słów ich wyrozumieniem idzie. Przyrzekamy [król - T. K.] we wszelakich sprawach inakszej nie czynić decyzyej nad prawo, własne brzmienie i opisanie słów, a gdzieby deklaracyej jakiej potrzeba do tej interpretacyej praw i przywilejów starych, posłowie mają też być przypuszczeni, gdyż jako nic nowego my z pany Radami bez wszech przyzwolenia stanowić nie możemy tak też w interpretacyą praw, które wszem obywatelom służą, bez posłów wdawać się nie mamy (...)", Dyjaryjusze sejmowe r. 1587: sejmy konwokacyjny i elekcyjny, wyd. A. Sokołowski, „Scriptores Rereum Polonicarum”, t. XX, Kraków 1887, s. 252. Szereg szczególnie symptomatycznych opinii dotyczących zasady clara noin sunt interpretanda odnajdujemy w znakomitym diariuszu jednego z najwybitniejszych polityków panowania Zygmunta III i Władysława IV, Jakuba Sobieskiego, z sejmu koronacyjnego 1633 r. W trakcie obrad posłowie twierdzili, iż: „,W interpretacyje (...) przychodzić nie dadza, ale quod scriptum, scriptum”, dodając, że „lex non disputant sed iubet”. Podkreślali również, iż nie należy „contra legem expressam rationibus persuadere”. Kanclerz Jerzy Ossoliński ubolewał przy tym, na kanwie jednej z uchwał, że ,interpretatio impedivit legem”, por. J. Sobieski, Diariusz sejmu koronacyjnego 1633 r., wyd. W. Kaczorowski, przy współudziale J. Dorobisza i Z. Szczerbnika, Opole 2008, s. 123, 145, 163.

110 „(...) warowały to u nas Stany Koronne y W. X. Lit. cum Provincijs annexis, żeby cokolwiek za Atecessorów naszych, Królów Polskich ex orbita wypadło przeciw prawu pospolitemu wszystko 
Teoria traktująca praktykę konstytucji objaśniających jako dokonywanie przez sejm autentycznej wykładni jest nad wyraz kusząca dla badacza. Po pierwsze, takie zaszeregowanie tego typu konstytucji sugeruje semantyczne znaczenie stosowanego przy nich określenia: „objaśnienie”. Po drugie, charakter egzorbiancyjny uchwał „objaśniających” i ich odrębność od tzw. „nowych praw" byłby przy takim traktowaniu widoczne najwyraźniej. Wykładnia prawa jest z zasady odpowiedzią na pojawiające się trudności z prawidłowym rozumieniem i stosowaniem obowiązującego prawa. Jednakże niechęć do jakiegokolwiek interpretowania, uważanego za idealne, prawa była w społeczeństwie szlacheckim olbrzymia. Jak zauważył na sejmie koronacyjnym z 1633 r. poseł Koryciński: „(...) gdybyśmy pociagać rationibus, albo interpretacyjami mieli prawo, toby non dessent, ale będziemy eksorbitancyją naprawować (...)"111. Świadczy to, iż odróżniano interpretację prawa od uchwalanych na sejmach konstytucji egzorbitancyjnych. Sprawa wymaga oczywiście dalszych badań z wykorzystaniem w znacznie szerszym zakresie źródeł diariuszowych i publicystycznych, choć trudno się spodziewać, by wyklarował się w tym zakresie jednoznaczny zestaw wniosków.

Niezależnie od kwestii powyższych możemy stwierdzić, iż „objaśnianie” konstytucji polegało na tworzeniu regulacji prawnych, których celem było potwierdzenie obowiązywania istniejących już norm i zagwarantowanie ich respektowania oraz efektywnego egzekwowania przez organy administracji publicznej i wymiaru sprawiedliwości. Należy dodać, iż odróżniano je od uchwałodawstwa w sensie ścisłym, czyli tworzenia nowych praw, stąd zasadą było wywoływanie przez nie skutków prawnych ex tunc, czego jednak nie uważano za łamanie zasady lex retro non agit. Świadczy o tym brak w przepisach „objaśniających” klauzul dotyczących ewentualnych kolizji temporalnych, towarzyszących z zasady stanowionym w Rzeczypospolitej prawom $^{112}$.

to w klubę swa wprawić y do exekucyi swoiei przywieść, tak iakoby się w niczym prawu pospolitemu nie derogowało, nie dopuszczając praw inaczey interpretować, tylko iako które w sobie brzmią [podkr. - T. K.]; ani na exempla przeciwne respektując (...)”, por. VL t. III s. 364-365, fol. 767 , t. IV, s. 95 , fol. 197 , t. V, s. 18 , fol. 28 , s. 145 , fol. 275 , s. 23-24, fol. 36-37. Wzmianki o takim postrzeganiu wykładni znajdujemy również w tekstach konstytucji: „,...) w sądzeniu spraw (...) z duchownemi religiey Rzymskiey y Greckiey, prawu (...) w konstytucyi roku 1689 ubliżenie się dzieie: przeto authoritate Seymu teraźnieyszego stanowimy, aby ten artykuł tak był rozumiany iako sam w sobie iest y słowa iego brzmią [podkr. - T. K.] (...)”, VL, t. II, s. 468, fol. 1673. „A to prawo in suo robore zostawać ma tak, iako samo w sobie brzmi, ani przez żadne interpretacye nie ma mu bydź nic przydano, ani uięto" [podkr. - T. K.], VL, t. IV, s. 6, fol. 4.

111 J. Sobieski, op. cit., s. 123.

${ }^{112}$ Problem przepisów retroaktywnych i klauzul ustalających moment, od którego nowe przepisy mają wywoływać skutki prawne, dogłębnie analizuje H. Grajewski, op. cit., passim. Niestety autor pomija milczeniem te przepisy, w których treści w ogóle brakuje wzmianki o momencie, od którego norma wywołuje skutki prawne. 
VI. Podsumowanie. Podsumowując powyższe rozważania, pragniemy podkreślić, iż konstytucje sejmowe, postrzegane zarówno jako najistotniejsze źródło prawa pospolitego przedrozbiorowej Rzeczypospolitej, jak i jako oryginalny instrument legislacyjny feudalnej Europy nadal wymagają pogłębionych badań. Mimo szerokiej dostępności drukowanych Voluminów Legum i przedsięwzięcia godnych pochwały prac publikacyjnych w zakresie zbioru Volumina Constitutionum, efekty egzegezy tych aktów, szczególnie w analizie techniki legislacyjnej, języka prawnego i prawniczego oraz ujmowania i kształtu poszczególnych instytucji prawnych, trudno uznać za zadowalające, zwłaszcza wobec braku koherencji wewnątrz konstytucji i niespójności logicznej i terminologicznej w konstruowaniu poszczególnych norm, co znacząco utrudnia współczesnemu badaczowi lokalizowanie i definiowanie prawidłowości w nich występujących. Zaskakująco niewiele wiadomo o egzekucji konstytucji, a więc o realnym wpływie ich tekstów na praktykę administracyjną i orzecznicza.

Szkic niniejszy, oparty w głównej mierze na analitycznej metodzie egzegezy tekstu prawnego, ze względu na swe niewielkie rozmiary omawia tylko pewne schematy modelowe, nie uwzględnia wszystkich odrębności, a także wielu problemów dyskusyjnych. Sposób formułowania konstytucji, używany w nich język, wielość pojawiających się na ich kartach określeń synonimicznych, konstruowanie przez ich autorów zdań wielokrotnie złożonych, pełnych niejasnych i niedookreślonych pojęć, oraz stosowanie licznych praktyk „rozmywania" sensu normy, wtrącania zastrzeżeń i asekuracji, a także mnożenie wyjątków, stanowią poważną trudność dla badacza. Wyżej zarysowanych konstatacji i wniosków nie należy zatem traktować jako stanowczych i rozstrzygających, mają one bowiem charakter hipotez badawczych, które wymagają dalszych kompleksowych i wielowymiarowych analiz.

CONSTITUTIONS OF SO-CALLED EXORBITANT PARLIAMENTS IN THE NOBLE REPUBLIC OF POLAND BETWEEN 1607 AND 1648

S u m m a r y

The subject of this paper is the legislative activity in the field of repair and reconstructions, called exorbitance, of parliaments of the Noble Republic of Poland before the Partitions. To prove his arguments, the author has adopted a thesis that each normative result of the parliamentary activity that required a consent of the three estates in the parliament ought to be termed a parliamentary constitution. The consequence of the above assumption is a belief that the Seym (parliament) constitutions are of heterogenic character. One of the main criteria of the qualification of the internal 
Seym constitutions is their legal character. The author is of the opinion that constitutions should be divided into four categories: (i) those that make law (contemporarily known as legal acts); (ii) administrative constitutions (being results of the work of the parliament as an organ of administration); (iii) exorbitant constitutions (resulting from the work of the parliament as an organ of state control); and (iv) procedural constitutions (relating to the procedure of a given Seym). The paper focuses in particular on the manner in which constitution's texts were formulated and the legislative techniques used, and analyses them in light of the Old Poland's legal culture.

\section{CONSTITUTIONS EXORBITANTES À L'ÉPOQUE DE LA RÉPUBLIQUE NOBILIAIRE DE POLOGNE ENTRE 1607 ET 1648}

\section{R é s u m e}

L'objet du présent article est l'activité législative des diètes générales, ayant lieu avant les démembrements territoriaux de la République nobiliaire de Pologne, en matière de la réparation de ce que l'on nommait « exorbitation » [abus du pouvoir royal, NDT]. Pour les besoins de sa démonstration, l'auteur admet la thèse suivante: chaque résultat normatif de l'activité de la diète, demandant l'accord de trois états parlementaires devrait être dénommé « constitution parlementaire ». La conséquence du principe ci-dessus est la constatation du caractère hétérogène des constitutions parlementaires et ceci non seulement au niveau de leur aspect objectif. L'un des critères les plus importants de la classification interne des constitutions parlementaires est leur caractère juridique. Selon l'auteur, les constitutions devraient être réparties en quatre catégories: celles qui créent de nouveaux droits (soit les actes législatifs au sens contemporain du terme); ensuite les constitutions administratives (soit les résultats de l'activité de la diète considérée comme organe d'administration); les constitutions exorbitantes (soit les résultats de l'activité de la diète considérée comme organe du contrôle d'État) ainsi que les constitutions procédurales (qui se réfèrent à la procédure de la diète même, à caractère particulier, à savoir recès et constitution habilitant à convoquer les séances de la diète extraordinaire). Dans la partie essentielle de ses réflexions focalisées sur les constitutions exorbitantes, l'auteur démontre qu'elles pouvaient « récapituler » (confirmer) les normes en vigueur durant la période donnée, les « expliquer » (c'est-à-dire compléter de détails techniques, éventuellement procéder à une interprétation authentique), soit abolir les décisions administratives, éventuellement les décisions du tribunal rendues en violation des normes du droit commun généralement applicable. La présente analyse porte notamment sur la formulation des textes des constitutions exorbitantes. Dans cet objectif, l'auteur a effectué une analyse approfondie des techniques législatives qu'elles utilisaient, par rapport à l'ancienne culture juridique polonaise. 